COORDENAÇÃO CENTRAL DE EXTENSÃO - CCE

Direito da Propriedade Intelectual

A publicidade comparativa e o direito do

consumidor à informação

Fernanda Varella Beser

Orientador: Prof. Pedro Marcos Nunes Barbosa 
Fernanda Varella Beser

\section{A publicidade comparativa e o direito do consumidor à} informação

Monografia apresentada ao Programa de Pós-Graduação em Direito da Propriedade Intelectual da PUC-Rio como requisito parcial para obtenção do título de Especialista em Direito da Propriedade Intelectual. Aprovada pela Comissão Examinadora abaixo assinada.

Orientador: Prof. Pedro Marcos Nunes Barbosa

Rio de Janeiro

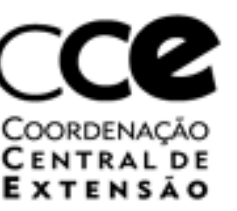


AGRADECIMENTOS

A Deus.

Aos meus pais, Eduardo e Regina, por tudo.

Ao meu orientador, Pedro Marcos Nunes Barbosa, por suas contribuições e apoio, fundamentais para a realização deste trabalho.

Aos meus queridos amigos, por todo o carinho e incentivo.

Aos animais mamíferos. Especialmente aos marinhos. 
"A publicidade é o processo privilegiado de (des)educação das massas na sociedade de consumo".

José de Oliveira Ascensão. 


\section{SUMÁRIO}

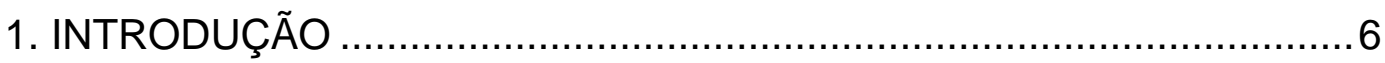

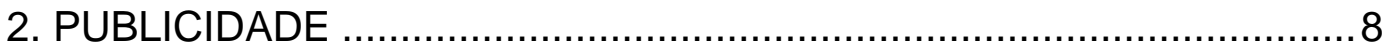

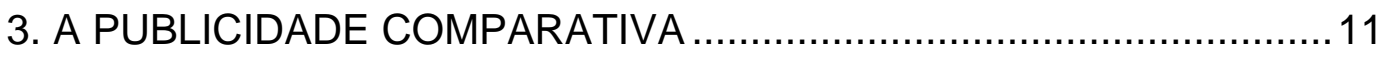

3.1. TRATAMENTO NA LEGISLAÇÃO ESTRANGEIRA ....................14

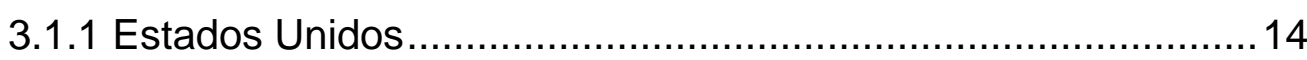

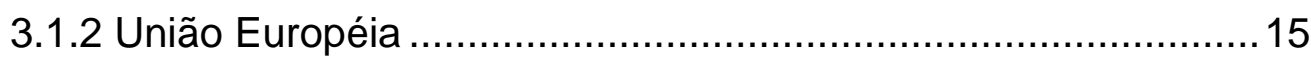

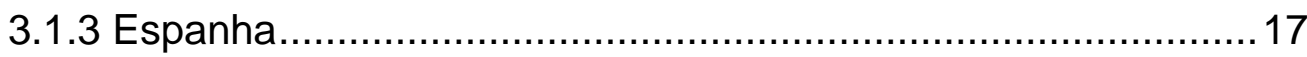

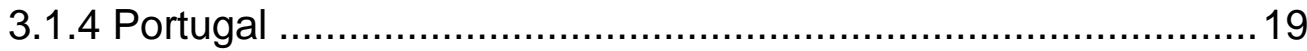

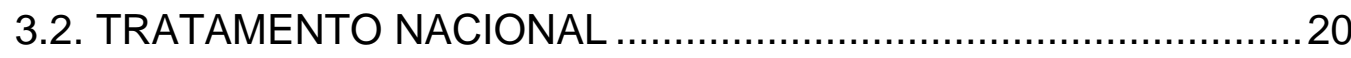

3.3. CONFLITOS COM DIREITO MARCÁRIO ..................................23

3.4. CONFLITOS COM DIREITO AUTORAL ......................................28

4. O DIREITO À INFORMAÇÃO NA SEARA CONSUMERISTA..............33

4.1. O PRINCÍPIO DA TRANSPARÊNCIA MÁXIMA NAS RELAÇÕES

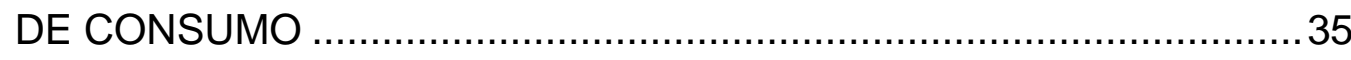

4.2. O PRINCÍPIO DA VERACIDADE E DA NÃO-ABUSIVIDADE NA PUBLICIDADE .......................................................................

4.3. PUBLICIDADE COMPARATIVA COMO FERRAMENTA DO

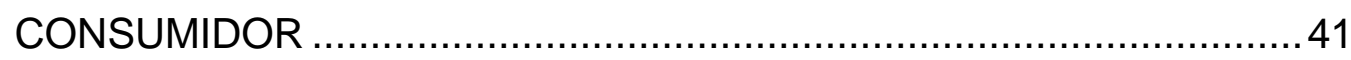

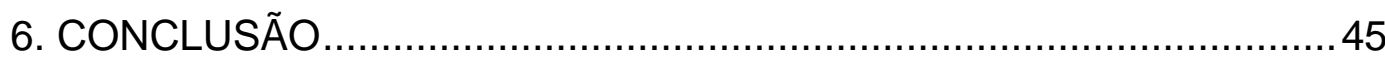

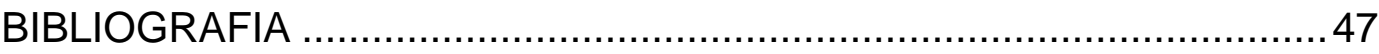




\section{INTRODUÇÃO}

Todos os dias o homem comum adquire produtos e contrata serviços, desde os mais simples e corriqueiros até os mais complexos. Tais contratos respondem a diversos anseios do consumidor, desde atender suas necessidades básicas de alimentação, vestuário, transporte e lazer, até a saciar sua vaidade e impulso consumista ${ }^{1}$.

No jogo das relações de consumo, a publicidade desempenha um papel fundamental, estabelecendo o diálogo entre o consumidor e o fornecedor. A publicidade desperta 0 interesse dos consumidores sobre seu objeto e leva a eles as primeiras informações sobre aquilo que se pretende adquirir.

O diálogo entre fornecedor e consumidor pode se estabelecer através de diversos meios, desde o primitivo "boca-a-boca" até a utilização da internet, e utilizar variadas técnicas, como a publicidade direta, uso de teasers, disseminação de conteúdo "viral", publicidade direcionada e, finalmente, a publicidade comparativa.

O presente trabalho tem por objetivo analisar a publicidade comparativa, em especial à luz do direito do consumidor e das normas que disciplinam a propriedade intelectual.

Este estudo se inicia com a conceituação de publicidade comparativa e com a apresentação de conceitos a ela relacionados, a fim de estabelecer de forma clara o escopo do presente trabalho.

A seguir, analisaremos o tratamento que a matéria recebeu em outros países, notadamente nos Estados Unidos, Espanha, Portugal e França.

\footnotetext{
1 "O consumismo de hoje, porém, não diz mais respeito à satisfação das necessidades - nem mesmo as mais sublimes, distantes (alguns diriam, não muito corretamente, "artificiais': "inventadas': "derivativas") necessidades de identificação ou a auto-segurança quanto à "adequação': Já foi dito que o spiritus movens da atividade consumista não é mais o conjunto mensurável de necessidades articuladas, mas o desejo - entidade muito mais volátil e efêmera, evasiva e caprichosa, e essencialmente não-referencial que as "necessidades': um motivo autogerado e autopropelido que não precisa de outra justificação ou "causa': A despeito de suas sucessivas e sempre pouco duráveis reificações, o desejo tem a si mesmo como objeto constante, e por essa razão está fadado a permanecer insaciável qualquer que seja a altura atingida pela pilha dos outros objetos (físicos ou psíquicos) que marcam seu passado". BAUMAN, Zygmunt. Modernidade Líquida. Rio de Janeiro: Zahar Editora, 2001. p. 88.
} 
Após, será estudado o tratamento nacional dado à publicidade comparativa, com a análise das normas que permeiam a matéria, em especial o Código de Defesa do Consumidor. Será objeto de estudo, ainda, o Código Brasileiro de Autorregulamentação Publicitária.

Passada esta análise, nos deteremos na verificação de possíveis conflitos com o direito marcário e com o direito autoral que possam advir do emprego da publicidade comparativa como ferramenta comercial.

Ainda, a possibilidade de conflitos será analisada sob a ótica da concorrência desleal, através da verificação da conduta que deverá ser observada pelo anunciante ao optar pela utilização de anúncio comparativo.

No capítulo seguinte será enfocado o direito à informação do consumidor, através da análise da sua previsão constitucional, seu desdobramento na legislação consumerista e os princípios aplicáveis.

Por último, será analisada a necessidade de ponderação dos interesses dos atores envolvidos nas relações de consumo e concorrência, quais sejam, o anunciante que emprega a publicidade comparativa, seus concorrentes e os consumidores. 


\section{PUBLICIDADE}

É muito comum e compreensível a confusão que geralmente permeia o uso dos termos "marketing", "propaganda" e "publicidade". Embora os vocábulos apresentem diferentes significados, é comum que sejam usados de forma indiscriminada, muitas vezes como sinônimos.

O marketing consiste em uma série de ações que vão desde a concepção de um produto (criação de sua marca, embalagem, invólucro, posicionamento no mercado), passando pela análise do mercado em que tal produto está inserido, até a elaboração de estratégias de vendas e de comunicação com o público consumidor.

A propaganda e a publicidade são ambas, portanto, ações de marketing. Muito embora este dois termos sejam comumente utilizados sem critério tanto no âmbito comercial quanto no âmbito legislativo, costuma-se dizer que, embora ambas tenham a finalidade de comunicar uma mensagem ao público, a publicidade o faria apenas com intuito comercial $^{23}$. Já a propaganda daria preferência à veiculação de uma idéia ${ }^{4}$, mormente com conotação política, ideológica, religiosa, filosófica, econômica ou social.

Da análise da legislação que regulamenta as atividades de propaganda e publicidade no país e outras que dispõem sobre a matéria, conclui-se que ambos os termos são usados sem maiores distinções, como verificamos a seguir.

\footnotetext{
2 "A publicidade não é só conteúdo. Ou seja, não traz, tão-somente, a informação sobre o produto ou serviço. Ela é, principalmente, forma, isto é, ela veicula uma mensagem que busca despertar na mente do consumidor a necessidade de consumir. A publicidade poderia ser definida, então, como a arte de criar necessidades, ela muitas vezes não se detém em considerações de ordem ética, moral ou social, atropelando valores culturais para vender produtos ou serviços, ou mesmo aproveitando a inexperiência da criança ou de outras classes de consumidores com baixa capacidade crítica.". JACOBINA, Paulo Vasconcelos. A Publicidade no Direito do Consumidor. Rio de Janeiro: Editora Forense, 1996. p.95.

3 "Filmes publicitários são aqueles destinados ao público consumidor de produtos ou de serviços de qualquer natureza, cuja finalidade é a promoção ou o aumento das vendas, ou da melhoria da imagem do anunciante. Os anúncios comerciais são aqueles diretamente relacionados à comercialização de produtos e serviços. (...)". ABRÃO, Eliane Yachouh. Direitos de autor e direitos conexos. São Paulo: Editora do Brasil, 2002. p. 111

${ }^{4}$ BENJAMIN, Antonio Hermann de Vasconcellos e. Código Brasileiro de Defesa do Consumidor comentado pelos autores do anteprojeto. 8. Ed. Rio de Janeiro: Forense, 2005, p.307. apud PEREIRA.
} 
A Constituição Federal adota o termo "propaganda comercial" para se referir às atividades publicitárias, conforme se verifica no art. 22, XXIX, o qual dispõe sobre a competência privativa da União para legislar sobre a matéria:

Art. 22. Compete privativamente à União legislar sobre:

XXIX - propaganda comercial.

Nossa Constituição utiliza o mesmo termo, ainda, em seu artigo 220, $\S 3^{\circ}$, II e $\S 4^{\circ}$ :

Art. 220. A manifestação do pensamento, a criação, a expressão e a informação, sob qualquer forma, processo ou veículo não sofrerão qualquer restrição, observado o disposto nesta Constituição.

$\S 3^{\circ}$ - Compete à lei federal:

$(\ldots)$

II - estabelecer os meios legais que garantam à pessoa e à família a possibilidade de se defenderem de programas ou programações de rádio e televisão que contrariem o disposto no art. 221, bem como da propaganda de produtos, práticas e serviços que possam ser nocivos à saúde e ao meio ambiente.

$\S 4^{0}$ - A propaganda comercial de tabaco, bebidas alcoólicas, agrotóxicos, medicamentos e terapias estará sujeita a restrições legais, nos termos do inciso II do parágrafo anterior, e conterá, sempre que necessário, advertência sobre os malefícios decorrentes de seu uso.

O Código Civil empregou a mesma nomenclatura ao disciplinar, em seu artigo 18, o uso de nome civil alheio em anúncios publicitários ${ }^{5}$.

Já o Código de Defesa do Consumidor utiliza de forma predominante o vocábulo "publicidade", tendo inclusive utilizado o termo no título de sua Seção III ("Da publicidade"). O CDC, entretanto, estabelece, em seus

\footnotetext{
5 "Art. 18. Sem autorização, não se pode usar nome alheio em propaganda comercial."
} 
artigos 56, XII e 60, como uma das possíveis sanções à publicidade enganosa ou abusiva a imposição de "contrapropaganda", o que mantém a confusão sobre o emprego correto dos dois termos.

Por sua vez, a Lei 4.680/1965, que dispõe sobre o exercício da profissão de publicitário e de agenciador de propaganda emprega o termo "propaganda" como se fosse sinônimo de "publicidade".

Da mesma forma a Lei 5.768/1071, que regulamenta a distribuição gratuita de prêmios, mediante sorteio, vale-brinde ou concurso utiliza as expressões "propaganda", "propaganda comercial" e "promoção publicitária".

Ao longo deste trabalho optamos por utilizar apenas a expressão "publicidade", a fim de conferir homogeneidade ao estudo e evitar contradições conceituais. 


\section{A PUBLICIDADE COMPARATIVA}

A publicidade comparativa é uma técnica publicitária que consiste em, como o próprio nome sugere, comparar o produto ou serviço anunciado com outros disponíveis no mercado.

ANXO TATO PLAZA ${ }^{6}$ conceitua a publicidade comparativa como sendo "aquella publicidad em la que el empresário anunciante compara su oferta con la de uno o vários competidores, identificados o inequivocamente identificables, com el resultado, directo o indirecto de resaltar las ventajas de los productos o servicios frente a los ajenos ${ }^{7 "}$.

Para MARCO ANTONIO MARCONDES PEREIRA ${ }^{8}$ :

(...) a publicidade comparativa, assim, consiste em método, ou técnica, de confronto empregado por um anunciante, destinado a assemelhar ou enaltecer, direta ou indiretamente, as qualidades ou preço de seus produtos ou serviços, em relação a produtos ou serviços de um ou mais concorrentes.

Para NATHALIA MAZZONETTO" "o conceito de publicidade comparativa não pressupõe a explícita identificação dos bens e serviços dos concorrentes e a eles menção específica. De outro lado, de rigor o confronto com produtos ou serviços de um ou mais concorrentes".

Já LELIO DENICOLI SCHMIDT" destaca que "entre as várias técnicas que podem ser manipuladas pela publicidade, insere-se a comparação do produto ou serviço do anunciante com os produtos ou

\footnotetext{
${ }_{7}^{6}$ PLAZA, Anxo Tato. La Publicidad Comparativa. Madrid: Marcial Pons, 1996. Apud PEREIRA.

7 "aquela publicidade na qual o empresário anunciante compara sua oferta com a de um ou vários competidores, identificados ou inequivocamente identificáveis, com o resultado, direto ou indireto de ressaltar as vantagens dos produtos ou serviços frente aos alheios". (Tradução livre)

${ }^{8}$ PEREIRA, Marco Antonio Marcondes. A ilicitude da publicidade comparativa. São Paulo: PUCSP, 2008. 237 p. Tese (Doutorado) - Doutorado em Direito, Pontifícia Universidade Católica de São Paulo, São Paulo, 2008.

${ }^{9}$ MAZZONETTO, Natalia. A publicidade comparativa e a prática de concorrência desleal por meio do denegrimento de marca e da imagem do concorrente. Revista da Associação Brasileira da Propriedade Industrial, Rio de Janeiro, n. 99, Mar/Abr de 2009, p. 3-20.

${ }^{10}$ SCHMIDT, Lelio Denicoli. A publicidade comparativa à luz da propriedade industrial. Revista da Associação Brasileira da Propriedade Industrial, Rio de Janeiro, n. 52, Mai/Jun de 2001, p. 3-17.
} 
serviços de seus concorrentes. Esta publicidade comparativa se alicerça em informações que procuram realçar o produto ou serviço do anunciante, pondo-o em confronto com produto ou serviço alheio, seja para demonstrar a superioridade do primeiro sobre o segundo, seja para igualá-los e assim permitir que aquele usufrua do padrão de qualidade por este ostentado no mercado".

O Federal Trade Comission dos Estados Unidos, em parecer datado de 13 de Agosto de $1979^{11}$, define a publicidade comparativa como:

comparative advertising is defined as advertising that compares alternative brands on objectively measurable attributes or price, and identifies the alternative brand by name, illustration or other distinctive information ${ }^{12}$.

Como vimos, a utilização da técnica de publicidade comparativa pode ocorrer de forma explícita ou implícita.

A publicidade comparativa será explícita quando houver uma menção expressa à marca ou ao nome do concorrente comparado ou, ainda, quando são utilizadas imagens do produto comparado ou do próprio estabelecimento concorrente.

A comparação será implícita quando não houver menção direta, mas o anunciante utilizar elementos que permitam a identificação do concorrente por parte do público consumidor. $\mathrm{O}$ anunciante oferece ao público sugestões ou indicativos que permitem a identificação, como a utilização de expressões como "a marca líder"13, "a marca x", referências aos slogans e campanhas do concorrente ${ }^{14}$, ou, ainda, a exibição de

\footnotetext{
${ }^{11}$ UNITED STATES FEDERAL TRADE COMISSION. Statement of Policy Regarding Comparative Advertising. Disponível em <http://www.ftc.gov/bcp/policystmt/ad-compare.htm>, acesso em $15 / 03 / 2011$

12 "Publicidade comparativa é definida como publicidade que compara marcas alternativas através de atributos mensuráveis ou preço, e identifica a marca alternativa pelo nome, ilustração ou outra informação distintiva" (Tradução livre).

13 "A Johnson \& Johnson protestou contra informações no site da LM Farma sobre seus produtos Curatec que traziam referências ao "líder do mercado" da categoria, que seria o J\&J Profissionais. Segundo a denúncia, trata-se de propaganda comparativa enganosa, pois as afirmações sobre o desempenho dos produtos em relação ao "líder de mercado" contrariam o disposto em suas bulas e embalagens. (...) Além disso, destacou que, ao ver o produto concorrente classificado como "líder do mercado", fica tacitamente aceito que a referência é ao nosso mercado, e não ao mercado europeu. Seu voto pela alteração da peça foi aceito unanimemente". Decisão da Representação no. 232/06 do CONAR.

14 "2. Anúncios dos denunciantes, do produto PRESTO BARBA, todos se lembram, teriam consagrado o texto: "O único com duas lâminas da Gillete. A primeira faz 'TCHAM' a segunda faz
} 
imagens que remetam ao concorrente, como uso das cores características $^{15}$, exibição de embalagens com trade dress semelhante no anúncio $^{16}$.

Há ainda o emprego da publicidade comparativa quando o anunciante apresenta uma afirmativa de superioridade ${ }^{17}$ em relação aos demais concorrentes, propagando-se como tendo a melhor qualidade, melhor desempenho ou melhor preço do mercado ${ }^{18}$.

'TCHUM' e 'TCHAM, TCHAM, TCHAM, TCHAM'!". O anúncio ora denunciado se utiliza da expressão "um tcham a mais", como por exemplo no material publicitário exposto a fls. 44 do processo: "PRONTO II. O único com um 'TCHAM' a mais. 3. Na referência ao "tcham" os denunciantes vêem a concorrência desleal e uma comparação entre produtos não abrigada pelo Código Ético. (...) A maioria da Câmara entendeu que a expressão "UM TCHAN A MAIS", isoladamente, não infringe a ética por ser considerada uma expressão usual e corriqueira. (...)". Relatório e decisão da Representação no 064/89 do CONAR.

15 "Propaganda da Pepsi em TV mostra dois limões conversando com um terceiro, sendo que este, prateado e de pernas vermelhas, apresenta comportamento irritante, repetindo tudo o que os outros falam, e é taxado de concorrente chato. A Coca-Cola protestou, alegando concorrência desleal. Houve concessão de liminar suspendendo a veiculação da peça. A Pepsi alegou que a propaganda é de inegável bom humor e que não há prática de concorrência desleal, visto que a Pepsi foi realmente a primeira empresa a lançar o refrigerante cola com limão. Em seu parecer, o relator ponderou que fica clara na peça a referência à concorrência, mostrando o limão concorrente como inferior e pouco dotado. Sua recomendação pela alteração do comercial, retirando-se as referências injuriosas, foi aceita por maioria de votos". Decisão da Representação no 116/06.

16 "Mas o que mais choca, no comercial, é o desprezo votado aos produtos concorrentes (é elucidativo o gesto do personagem, do desprezo com que se desfaz desses produtos, um a um, jogando-os no chão) que, se não identificados pela marca, são-no pelas embalagens que, não obstante passarem velozmente, deixam ver a marca a que essas embalagens estão associadas. Note-se que as embalagens são reais e não simbólicas, caracterizando-se por aí a concorrência desleal, com que se infringiu o art. 4ํ do Código". Decisão da Representação nº 058/89 do CONAR.

17 Se tal afirmativa não for verídica, verifica-se a ocorrência da concorrência desleal, tal qual previsto na LPI, art. 195, VII: "Art. 195. Comete crime de concorrência desleal quem: VII - atribuise, como meio de propaganda, recompensa ou distinção que não obteve";

${ }_{18}$ "A alegação da reclamante era de que a Vivo estaria veiculando propaganda comparativa enganosa com claim de superioridade absoluta, ao afirmar que sua banda larga móvel é a mais rápida do mercado. Segundo a Claro, a pesquisa da revista InfoExame teria concluído que a Vivo seria superior à Claro nos atributos "navegação" e "download". Entretanto, a Claro seria superior no atributo "upload", o que impediria a utilização do claim de superioridade absoluta. A Vivo contestou esta linha de argumentação, enfatizando, entre outros aspectos, que a metodologia utilizada pela pesquisa atribui pesos distintos para "navegação", "download" e "upload", sendo que os dois primeiros receberam pesos de $50 \%$ e $40 \%$, respectivamente, enquanto upload teve $10 \%$. Em primeira instância, a relatora concordou com a defesa da Vivo, afirmando que, pela análise do material, foi evidenciado que, no conjunto, os serviços oferecidos pela Vivo são mais rápidos que os da Claro, o que justificaria o claim de superioridade". Decisão da Representação n. 062/08 do CONAR. 


\subsection{TRATAMENTO NA LEGISLAÇÃO ESTRANGEIRA}

\subsubsection{Estados Unidos}

Nos Estados Unidos é muito comum o uso de publicidades comparativas. São memoráveis os anúncios que opunham as famosas marcas de refrigerante Coca-Cola e Pepsi ${ }^{19}$ e hoje em dia chamam a atenção do público daquele país os comerciais que comparam os computadores da Mac ao seu concorrente, $\mathrm{PC}^{20}$.

A proliferação deste tipo de publicidade alhures pode ser explicada pelo encorajamento dado oficialmente, desde 1979, pelo Federal Trade Comission (FTC) que emitiu parecer ${ }^{21}$ naquele ano determinando que a autorregulamentação da indústria publicitária não deveria restringir o uso de publicidade comparativa com conteúdo verdadeiro.

O FTC declara que o uso da publicidade comparativa é benéfico aos anunciantes, às agências publicitárias, à mídia e às entidades de autorregulamentação. Declara ainda que deve ser encorajado o uso do nome do concorrente, ou referências a ele, desde que seja claro.

O órgão norte-americano manifesta, ainda, que a técnica comparativa, quando veículo de informações verdadeiras e nãoenganosas, é uma fonte importante de informações aos consumidores e os auxilia a tomar decisões racionais de consumo. Além disso, declara que o emprego de técnicas comparativas encoraja melhorias nos produtos e inovação, e poderia levar à redução de preços no mercado.

\footnotetext{
${ }^{19}$ Um dos anúncios mais lembrados mostra um menino que compra duas latas de Coca-Cola em uma máquina de refrigerantes, apenas para usá-las como apoio e ajudá-lo a alcançar o botão da Pepsi, mais alto. Vídeo disponível em

$<$ http://www.youtube.com/watch?v=WIgKmSW_DMA\&feature=related>, acesso em 27/02/2011.

${ }^{20}$ Um dos anúncios mostra um rapaz e um homem mais velho. O rapaz diz que finalizou um vídeo caseiro em seu Mac. Aparece, então, a modelo Gisele Bündchen, anunciando ser um "vídeo caseiro Mac". Logo em seguida o homem mais velho anuncia que também fez um vídeo caseiro em seu PC e logo vemos um homem, usando uma peruca loira e o mesmo vestido de Gisele Bündchen, dando a clara impressão que os vídeos feitos em PC têm qualidade inferior aos vídeos feitos em um Mac. Vídeo disponível em:

$<\mathrm{http}: / /$ www.youtube.com/watch?v=KNnX6XRQBec>, acesso em 27/02/2011.

${ }^{21}$ UNITED STATES FEDERAL TRADE COMISSION. Statement of Policy Regarding Comparative Advertising. Disponível em <http://www.ftc.gov/bcp/policystmt/ad-compare.htm>, acesso em $15 / 03 / 2011$
} 


\subsubsection{União Européia}

A atividade normativa da União Européia introduz mudanças notáveis em âmbitos distintos do mercado, que apresentam uma intensa relação entre si, como a concorrência desleal, a publicidade e a proteção dos consumidores.

Neste sentido, a União Européia vem editando diversas Diretivas sobre tais matérias. Notadamente, uma das primeiras mudanças foi introduzida pela Diretiva 2005/29/CE do Parlamento Europeu e do Conselho, de 11 de maio de 2005, relativa à práticas comercias desleais das empresas em suas relações com os consumidores no mercado interno.

Em segundo lugar, uma significativa mudança foi introduzida pela Diretiva 2006/114/CE do Parlamento Europeu e do Conselho, de 12 de dezembro de 2006, sobre publicidade enganosa e publicidade comparativa, que codifica as modificações da Diretiva 84/450/CE.

A Diretiva 84/450/CE, do Conselho, de 10 de Setembro de 1984, relativa à publicidade enganosa e à publicidade comparativa, foi alterada várias vezes de modo substancial, sendo conveniente, por uma questão de lógica e clareza, proceder à sua codificação ${ }^{22}$.

A 2006/114/CE propõe que, se suas regras forem devidamente respeitadas, tal contribuirá para demonstrar de forma objetiva as vantagens dos diferentes produtos comparáveis. A Diretiva também afirma que a publicidade comparativa pode ainda estimular a concorrência entre fornecedores de bens e serviços no melhor interesse dos consumidores $^{23}$.

Desta forma, a Diretiva estabelece que a publicidade comparativa, quando compara características essenciais, pertinentes, comprováveis e representativas dos produtos ou serviços anunciados e não é enganosa,

\footnotetext{
22 Diretiva 2006/114/CE: "Considerando o seguinte: (1) A Directiva 84/450/CEE, do Conselho, de 10 de Setembro de 1984, relativa à publicidade enganosa e comparativa, foi alterada várias vezes de modo substancial sendo conveniente, por uma questão de lógica e clareza, proceder à sua codificação".

23 Diretiva 2006/114/CE: "Considerando o seguinte: (8) A publicidade comparativa, quando compara características essenciais, pertinentes, comprováveis e representativas e não é enganosa, pode constituir um meio legítimo de informar os consumidores das vantagens que lhe estão associadas. É desejável prever uma definição ampla de publicidade comparativa que cubra todos os tipos de publicidade comparativa".
} 
pode constituir um meio legítimo de informar os consumidores das vantagens que lhe estão associadas.

Importante mencionar que a Diretiva estabelece expressamente que a utilização da marca, da designação comercial ou de qualquer outra marca distintiva de outrem não infringe o direito exclusivo do titular, na medida em que se dê cumprimento às regras da diretiva ${ }^{24}$.

Desta forma, a Diretiva 2006/114/CE permite expressamente a utilização da publicidade comparativa como ferramenta comercial e estabelece em seu artigo $4^{\circ}$ as condições para uso de tal técnica.

O critério primordial para a aceitação da publicidade comparativa é que ela não seja enganosa na acepção da alínea "b" do artigo $2^{2025}$, do artigo $3^{0^{26}}$ e da citada diretiva ou, ainda, dos artigos $6^{0^{27}}$ e $7^{\circ}$ da Diretiva

\footnotetext{
${ }^{24}$ Diretiva 2006/114/CE: "Considerando o seguinte: (15) A utilização da marca, da designação comercial ou de qualquer outra marca distintiva de outrem não infringe o direito exclusivo do titular, na medida em que se dê cumprimento às regras da presente diretiva, já que o objetivo consiste apenas em acentuar objetivamente as respectivas diferenças".

${ }_{25}$ "Art 2․ b) «Publicidade enganosa»: a publicidade que, por qualquer forma, incluindo a sua apresentação, induz em erro ou é susceptível de induzir em erro as pessoas a quem se dirige ou que atinge e cujo comportamento econômico pode afetar, em virtude do seu caráter enganador, ou que, por estas razões, prejudica ou pode prejudicar um concorrente".

26 "Art. 3ㅇ: Para determinar se uma publicidade é enganosa, devem ter-se em conta todos os seus elementos e, nomeadamente, todas as indicações que digam respeito: a) Às características dos bens ou serviços, tais como a sua disponibilidade, natureza, execução, composição, o modo e a data de fabrico ou de prestação, o caráter adequado, as utilizações, a quantidade, as especificações, a origem geográfica ou comercial ou os resultados que podem ser esperados da sua utilização, ou os resultados e as características essenciais dos testes ou controles efetuados sobre os bens ou serviços; b) Ao preço ou ao seu modo de estabelecimento, e às condições de fornecimento dos bens ou da prestação dos serviços; c) À natureza, às qualidades e aos direitos do anunciador, tais como a sua identidade e o seu patrimônio, as suas qualificações e os seus direitos de propriedade industrial, comercial ou intelectual, ou os prêmios que recebeu ou as suas distinções".

27 "Art. 6": 1. É considerada enganosa uma prática comercial se contiver informações falsas, sendo inverídicas ou que por qualquer forma, incluindo a sua apresentação geral, induza ou seja susceptível de induzir em erro o consumidor médio, mesmo que a informação seja factualmente correta, em relação a um ou mais dos elementos a seguir enumerados e que, em ambos os casos, conduza ou seja susceptível de conduzir o consumidor médio a tomar uma decisão de transação que este não teria tomado de outro modo: a) A existência ou natureza do produto; b) As características principais do produto, tais como a sua disponibilidade, as suas vantagens, os riscos que apresenta, a sua execução, a sua composição, os seus acessórios, a prestação de assistência pós-venda e o tratamento das reclamações, o modo e a data de fabrico ou de fornecimento, a entrega, a adequação ao fim a que se destina, as utilizações, a quantidade, as especificações, a origem geográfica ou comercial ou os resultados que podem ser esperados da sua utilização, ou os resultados e as características substanciais dos testes ou controles efetuados sobre o produto; c) O alcance dos compromissos assumidos pelo profissional, a motivação da prática comercial e a natureza do processo de venda, bem como qualquer afirmação ou símbolo fazendo crer que o profissional ou o produto beneficiam de um patrocínio ou apoio directos ou indirectos; d) O preço ou a forma de cálculo do preço, ou a existência de uma vantagem específica relativamente ao preço; e) A necessidade de um serviço, de uma peça, de uma substituição ou de uma reparação; f) A natureza, os atributos e os direitos do profissional ou do seu agente, como a sua identidade e o seu património, as suas qualificações, o seu estatuto, a sua aprovação, a sua inscrição ou as suas relações e os seus direitos de propriedade industrial, comercial ou intelectual, ou os prémios e distinções que tenha recebido; g) Os direitos do consumidor, em particular o direito de substituição ou de reembolso nos termos do disposto na Directiva 1999/44/CE do Parlamento Europeu e do
} 
2005/29/CE, relativa às práticas comerciais desleais das empresas face aos consumidores no mercado interno.

No emprego da técnica da comparação, de acordo com a mencionada diretiva, o anunciante deverá ainda comparar bens ou serviços que se prestem ao mesmo $\mathrm{fim}^{28}$. O anunciante deverá, ainda, realizar uma comparação objetiva de uma ou mais características dos produtos, que Ihes sejam essenciais, pertinentes, comprováveis e representativas $^{29}$.

Ainda, na identificação do concorrente comparado, o anunciante não poderá "desacreditar ou depreciar marcas, designações comerciais, outros sinais distintivos, bens, serviços, atividades ou situação do concorrente" (art. 4ํㅇ).

A publicidade comparativa não poderá ser utilizada como artifício para que o anunciante se aproveite indevidamente do renome do concorrente comparado $^{30}$ e nem deverá apresentar o bem ou serviço anunciado como sendo imitação ou reprodução de outros ${ }^{31}$.

Por fim, a citada diretiva estabelece que o anúncio que adotar a técnica da comparação não poderá gerar confusão entre os concorrentes ou entre suas marcas ${ }^{32}$.

\subsubsection{Espanha}

A incorporação da Diretiva 2006/114/CE ao Direito Espanhol ocorreu através da edição de diversas leis, dentre as quais se destaca a Lei noㅡ

Conselho, de 25 de Maio de 1999, relativa a certos aspectos da venda de bens de consumo e das garantias a ela relativas, e os riscos a que pode estar sujeito".

${ }^{28}$ Art. $4^{\circ}$ : "b) Comparar bens ou serviços que respondem às mesmas necessidades ou têm os mesmos fins;"

29 Art. 40: "c) Comparar objetivamente uma ou mais características essenciais, pertinentes, comprováveis e representativas desses bens e serviços, entre as quais se pode incluir o preço;"

${ }^{30}$ Art 40: "f) Não tirar partido indevido do renome de uma marca, designação comercial ou outro sinal distintivo de um concorrente ou da denominação de origem de produtos concorrentes";

${ }^{31}$ Art. $4^{\circ}:$ " $g$ ) Não apresentar um bem ou serviço como sendo imitação ou reprodução de um bem ou serviço cuja marca ou designação comercial seja protegida";

32 Art. $4^{\circ}$ : "h) Não gerar confusão no mercado entre negociantes, entre o anunciante e um concorrente ou entre as marcas, designações comerciais, outros sinais distintivos, bens ou serviços do anunciante e do concorrente". 
29/2009, que modifica o regime legal da concorrência desleal e da publicidade, com o intuito de aprimorar os mecanismos de proteção aos consumidores.

No que tange à Publicidade Comparativa, o artigo 10 do Código Geral de Publicidade Espanhol, a fim de se adequar às diretivas da Comunidade Européia, permite expressamente a utilização da publicidade comparativa, desde que cumpridos os requisitos previstos na mesma lei ${ }^{33}$.

Dentre os requisitos estabelecidos estão a equivalência entre os produtos ou serviços comparados ${ }^{34}$ e a objetividade na comparação das características do objeto da análise ${ }^{35}$.

Ainda, no emprego da técnica, o anunciante não poderá apresentar seu produto ou serviço como sendo uma imitação ou réplica do concorrente comparado ${ }^{36}$.

Por fim, a lei espanhola estabelece que a comparação não poderá constituir-se em ato enganoso, em denigrimento ou exploração da reputação do concorrente comparado ${ }^{37}$.

\footnotetext{
33 "Artículo 10. Actos de comparación. La comparación pública, incluida la publicidad comparativa, mediante una alusión explícita o implícita a un competidor estará permitida si cumple los siguientes requisitos". (Tradução livre: "Artigo 10. Atos de comparação. A comparação pública, incluída a publicidade comparativa, mediante uma alusão explícita ou implícita a um competidor estará permitida se cumpre os seguintes requisitos").

34 "Artículo 10. a) Los bienes o servicios comparados habrán de tener la misma finalidad o satisfacer las mismas necesidades". (Tradução livre: "Artigo 10 a) Os bens ou serviços comparados deverão ter a mesma finalidade ou satisfazer as mesmas necessidades".

${ }_{35}$ "Artículo 10. b) La comparación se realizará de modo objetivo entre una o más características esenciales, pertinentes, verificables y representativas de los bienes o servicios, entre las cuales podrá incluirse el precio". (Tradução livre: "Artigo 10. B) A comparação realizar-se-á de modo objetivo entre uma ou mais características essenciais, pertinentes, verificáveis e representativas dos bens ou serviços, entre as quais se poderá incluir o preço").

36 "Artículo 10. d) No podrán presentarse bienes o servicios como imitaciones o réplicas de otros a los que se aplique una marca o nombre comercial protegido". (Tradução livre: "Artigo 10. D) Não poderá apresentar bens ou serviços como imitações ou réplicas de outros aos quais se aplique uma marca ou nome comercial protegido".)

37 "Artículo 10. e) La comparación no podrá contravenir lo establecido por los artículos 5, 7, 9, 12 y 20 en materia de actos de engaño, denigración y explotación de la reputación ajena". (Tradução livre: "Artigo 10. E) A comparação não poderá infringir o disposto pelos artigos 5, 7, 9, 12 e 20 em matéria de atos enganosos, denegrimento e exploração da repuutação alheia").
} 


\subsubsection{Portugal}

Em Portugal, a publicidade comparativa é regulada pelo artigo $16^{\circ}$ do Código Publicitário Português ${ }^{38}$, que permite de forma expressa sua veiculação, desde que observados os limites legais impostos ${ }^{39}$.

As restrições impostas à publicidade comparativa na lei portuguesa refletem as diretivas da Comunidade Européia, contemplando, como requisitos para o uso da técnica da comparação, a veracidade das informações veiculadas ${ }^{40}$, a equivalência dos produtos $\operatorname{comparados}^{41}$, e a objetividade dos critérios na comparação realizada ${ }^{42}$.

De acordo com o Código Publicitário Português, para a que a publicidade comparativa seja aceita é necessário, ainda, que o anúncio não gere confusão entre $o$ produto ou serviço anunciado e seu concorrente comparado ${ }^{43}$, nem o desacredite ou o deprecie ${ }^{44}$.

A exemplo da Diretiva 2006/114/CE e do Código Geral de Publicidade Espanhol, anteriormente analisados, o Código Publicitário Português também prevê que, no uso da técnica da comparação publicitária, o anunciante não deverá aproveitar-se do renome do concorrente comparado ${ }^{45}$, nem apresentar-se como sendo uma imitação ou réplica do produto ou serviço de referência ${ }^{46}$.

\footnotetext{
38 Decreto-Lei n. ${ }^{\circ} 330 / 90$.

39 "Artigo $16^{\circ}$ (Publicidade comparativa) 1 - É comparativa a publicidade que identifica, explícita ou implicitamente, um concorrente ou os bens ou serviços oferecidos por um concorrente; 2 - $A$ publicidade comparativa, independentemente do suporte utilizado para a sua difusão, só é consentida, no que respeita à comparação, desde que respeite as seguintes condições:"

40 "Artigo16 a) Não seja enganosa, nos termos do artigo 11".

41 "Artigo16 b) Compare bens ou serviços que respondam às mesmas necessidades ou que tenham os mesmos objetivos".

42 "Artigo16 c) Compare objetivamente uma ou mais características essenciais, pertinentes, comprováveis e representativas desses bens ou serviços, entre as quais se pode incluir o preço".

${ }_{43}$ "Artigo $16^{\circ}$ d) Não gere confusão no mercado entre o anunciante e um concorrente ou entre marcas, designações comerciais, outros sinais distintivos, bens ou serviços do anunciante ou de um concorrente".

44 "Artigo $16^{\circ}$ e) Não desacredite ou deprecie marcas, designações comerciais, outros sinais distintivos, bens, serviços, actividades ou situação de um concorrente".

45 "Artigo $\left.16^{\circ} \mathrm{g}\right)$ Não retire partido indevido do renome de uma marca, designação comercial ou outro sinal distintivo de um concorrente ou da denominação de origem de produtos concorrentes".

46 "Artigo $16^{\circ}$ h) Não apresente um bem ou serviço como sendo imitação ou reprodução de um bem ou serviço cuja marca ou designação comercial seja protegida".
} 


\subsection{TRATAMENTO NACIONAL}

Conforme verificamos, há diversos países que permitem expressamente a utilização da publicidade comparativa como ferramenta comercial $^{47}$. No Brasil, entretanto, inexiste previsão legal que discipline de forma específica a publicidade comparativa, seja para permiti-la ou proibi-la ${ }^{48}$.

$\mathrm{Na}$ falta de disciplina específica, nos casos de conflitos oriundos do emprego da técnica publicitária comparativa a doutrina e a jurisprudência vêm analisando a matéria, como veremos a seguir, à luz do direito marcário, do direito autoral e das normas de concorrência.

Apesar de inexistir lei que expressamente regulamente o assunto, o Código Brasileiro de Autorregulamentação Publicitária (CBARP), elaborado pelo Conselho Nacional de Autorregulamentação Publicitária (CONAR) dedica ao tema uma de suas seções.

O Conselho Nacional de Autorregulamentação Publicitária (CONAR) é uma organização não-governamental responsável pelo auto-controle do mercado publicitário, cujo principal objetivo é zelar pelo cumprimento do $\mathrm{CBARP}^{49}$, através da análise de denúncias formuladas por consumidores, autoridades, por seus associados ou ainda formuladas pela própria diretoria $^{50}$. O CONAR, destarte, "procura traçar os ditames éticos da

\footnotetext{
47 "O uso da Publicidade Comparativa, apesar de controvertida, constitui uma tendência mundial fomentada por um mercado cada vez maior, dados os fenômenos da globalização e da regionalização. Nos Estados Unidos, por exemplo, a liberdade de expressão sobrepõe-se a qualquer outro valor, desconsiderando, inclusive, o direito de propriedade. A Publicidade Comparativa é por eles considerada benéfica e amplamente aceita. Quanto aos países europeus, o tratamento conferido à questão não se dá de forma harmônica, razão pela qual a União Européia tem procurado amenizar as diferenças adotando as Diretivas, que são, na verdade, orientações. Lá, a concorrência é tida como essencial para a eficiência do capitalismo, pois evita o abuso de poder econômico". COELHO, Daniele Maia Teixeira. A publicidade comparativa e seu tratamento legal. Revista Forense, Vol. 354, 2001. p. 138.

48 "O Código de Defesa do Consumidor não regula a matéria, o que faz a doutrina, a nosso ver com acerto, considerando legal a prática publicitária comparativa, ante a ausência de vedação expressa nesse sentido". DA SILVA, Regina Beatriz Tavares da e POLETTO, Carlos Eduardo Minozzo. Responsabilidade Civil pela Publicidade. In SILVA, Regina Beatriz Tavares da (coord.), Responsabilidade Civil nas relações de consumo. São Paulo: Saraiva, 2009. p. 408.

49 "História - Uma breve história do CONAR". Disponível em : <conar.org.br>. Acesso em 23.11.2010.

50 "Feita a denúncia, o Conselho de Ética do Conar - o órgão soberano na fiscalização, julgamento e deliberação no que se relaciona à obediência e cumprimento do disposto no Código - se reúne e a julga, garantindo amplo direito de defesa ao acusado. Se a denúncia tiver procedência, o Conar recomenda aos veículos de comunicação a suspensão da exibição da peça ou sugere correções à
} 
profissão e, por conseqüente, dos materiais publicitários produzidos e dirigidos ao mercado" ${ }^{1}$.

Sobre a atuação do CONAR, cabe ainda mencionarmos que suas decisões cingem-se a analisar a eventual ocorrência de violação ética e a recomendar a alteração ou sustação da peça publicitária, não havendo a possibilidade de impor qualquer tipo de ressarcimento ou indenização ao denunciado ${ }^{52}$.

Destarte, no Brasil, o controle da publicidade pode ser feito na esfera privada, através de auto-controle ou no âmbito judicial, existindo, desta forma, um sistema de controle misto da publicidade ${ }^{53}$.

Sobre a conveniência de tal modelo, Newton De Lucca afirma que " 0 sistema misto - com participação estatal e privada da autodisciplina - se apresenta como o mais adequado para o estágio atual, motivo pelo qual acabou prevalecendo no nosso CDC". ${ }^{54}$

O CBARP, apesar de não gozar de status de lei, pode ser considerado uma importante fonte subsidiária de direito ${ }^{55}$, tendo em vista que expressa os usos e costumes do mercado publicitário ${ }^{56}$.

propaganda. Pode ainda advertir anunciante e agência”. Disponível em : <conar.org.br>. Acesso em 23.11.2010.

51 DA SILVA, Regina Beatriz Tavares da e POLETTO, Carlos Eduardo Minozzo. Responsabilidade Civil pela Publicidade. In SILVA, Regina Beatriz Tavares da (coord.), Responsabilidade Civil nas relações de consumo. São Paulo: Saraiva, 2009. p. 398.

52 “ O órgão, investido da legitimidade conferida por seus próprios associados, aplica penalidades que vão desde a advertência, passando pela recomendação de alteração de anúncio, indo até a suspensão da veiculação dele. Mas não aplica sanções econômicas do tipo indenizatórias. Assim, uma eventual contenda interna sobre apropriação de idéia publicitária não terá efeitos jurídicos patrimoniais, valendo apenas entre as partes envolvidas e associadas ao órgão julgador, com eventuais prejuízos, mas sem ressarcimentos". ABRÃO, Eliane Yachouh. Direitos de autor e direitos conexos. São Paulo: Editora do Brasil, 2002. p. 111

53 "Desse modo, podemos concluir que o sistema misto, ou seja, aquele em que dialogam e convivem normas e instâncias legais e administrativas no controle da publicidade ilícita, é o que vigora no País". DA SILVA, Regina Beatriz Tavares da e POLETTO, Carlos Eduardo Minozzo. Responsabilidade Civil pela Publicidade. In SILVA, Regina Beatriz Tavares da (coord.), Responsabilidade Civil nas relações de consumo. São Paulo: Saraiva, 2009. p. 399.

${ }^{54}$ DE LUCCA, Newton. Direito do Consumidor: aspectos práticos - perguntas e respostas. 2. Ed. Bauru: EDIPRO, 2000. Apud DA SILVA, Regina Beatriz Tavares da e POLETTO, Carlos Eduardo Minozzo. Responsabilidade Civil pela Publicidade. In SILVA, Regina Beatriz Tavares da (coord.), Responsabilidade Civil nas relações de consumo. São Paulo: Saraiva, 2009.

${ }^{55}$ Art. 4" do Decreto-Lei no. 4.657/42 (Lei de Introdução ao Código Civil): "Art. 4º Quando a lei for omissa, o juiz decidirá o caso de acordo com a analogia, os costumes e os princípios gerais de direito".

${ }^{56}$ Art. 16 do CBARP: "Embora concebido essencialmente como instrumento de autodisciplina da atividade publicitária, este Código é também destinado ao uso das autoridades e Tribunais como documento de referência e fonte subsidiária no contexto da legislação da propaganda e de outras leis, decretos, portarias, normas ou instruções que direta ou indiretamente afetem ou sejam afetadas pelo anúncio". 
A respeito da publicidade comparativa, o CBARP a aceita expressamente $^{57}$, limitando o seu uso aos princípios e requisitos previstos em seu artigo 32.

O princípio basilar da publicidade comparativa é a informação e o esclarecimento do consumidor ${ }^{58}$. As mensagens e informações contidas no anúncio que utiliza a técnica da comparação devem ser claras, corretas e precisas e devem ter como fito auxiliar o consumidor a realizar uma escolha de consumo consciente.

A exemplo das legislações estrangeiras anteriormente analisadas e em total consonância com elas ${ }^{59}$, o CBARP também estabelece como requisito básico para a utilização da técnica de comparação a equivalência ${ }^{60}$ entre os produtos comparados ${ }^{61}$, além da objetividade na

\footnotetext{
57 "Artigo32. Tendo em vista as modernas tendências mundiais - e atendidas as normas pertinentes do Código da Propriedade Industrial, a publicidade comparativa será aceita, contanto que respeite os seguintes princípios e limites:"

58 "Artigo 32. a. seu objetivo maior seja o esclarecimento, se não mesmo a defesa do consumidor". 59 "Tais diretrizes administrativas estão em total consonância com o disposto na legislação estrangeira, devendo ser observadas no momento da utilização da publicidade comparativa". DA SILVA, Regina Beatriz Tavares da e POLETTO, Carlos Eduardo Minozzo. Responsabilidade Civil pela Publicidade. In SILVA, Regina Beatriz Tavares da (coord.), Responsabilidade Civil nas relações de consumo. São Paulo: Saraiva, 2009. p. 409.

${ }^{60}$ Nesse sentido, destacamos a seguinte decisão do CONAR: "O Sr. Relator ofereceu o seguinte parecer, acolhido por unanimidade pela Câmara: '(...) Segundo sua queixa, o comercial, além de repetir várias vezes a palavra ou o som 'PLOC', mostra o ator dizendo ao final: 'Tablete Valda, melhor que esse PLOC aí!'. Em vista disso, com fundamento nos arts. 4o 14, 17, 32 e 43 do $C B A R P$, o denunciante requereu a sustação da veiculação do anúncio, inclusive através de medida liminar. (...). PARECER (...). 2. Aliás, é bom que se esclareça que o que está em discussão não é a palavra melhor. $O$ anúncio poderia rotular o produto como melhor sem que isto pudesse eventualmente provocar os reclamos de terceiros e sem ser considerado antiético. Mas no caso ele empregou a palavra para afirmar que 'Tablete Valda é melhor que esse Ploc aí!'. O consumidor fica esperando sem ser devidamente informado porque ele é melhor do que o outro produto. A defesa, neste particular, alega que a publicidade não é comparativa porque os produtos não são idênticos. Um é um confeito; o outro seria medicamento. Mas resulta evidente que o anúncio procura o mesmo 'target', isto é, o consumidor já habituado a outras gomas de mascar. Só que foi estruturado de maneira antiética. 3. Além disso, se os produtos são diferentes, o defeito reside no anúncio e não no enquadramento ético conferido à representação. (...) E a falta cometida pelo comercial afronta o espírito ético que inspirou a redação do referido art. 32, notadamente quando veda a comparação de produtos incomparáveis. 4. Em conseqüência, no meu entender, o anúncio não caracteriza a concorrência leal, cujo zelo é previsto no art. 4ํdo CBARP; procura deslustrar a imagem de terceiros em detrimento da recomendação prevista no art. 43 desse mesmo Código; e, sobretudo, procura confundir o consumidor, inclusive quando não esclarece o que é esclarecido na defesa, ou seja, de que se trata 'de um remédio com propriedades claramente definidas em sua bula (antisséptico para o tratamento de dor e irritações na garganta, rouquidão, pigarro e tosse)'. (...)"..CONAR, REPRESENTAÇÃO № 080/87, Relator: Cons ${ }^{\circ}$ Paulo Augusto de Almeida.

61 "Artigo 32. (...) d. em se tratando de bens de consumo a comparação seja feita com modelos fabricados no mesmo ano, sendo condenável o confronto entre produtos de épocas diferentes, a menos que se trate de referência para demonstrar evolução, o que, nesse caso, deve ser caracterizado; (...) h. quando se fizer uma comparação entre produtos cujo preço não é de igual nível, tal circunstância deve ser claramente indicada pelo anúncio.”.
} 
comparação $^{62}$. É necessário, ainda, que a comparação seja comprovável ${ }^{63}$.

O CBARP prevê ainda determinados requisitos para o uso da publicidade comparativa que visam a resguardar os interesses dos concorrentes, como a determinação de que não se estabeleça confusão entre o produto anunciado e o concorrente comparado ${ }^{64}$.

Ainda no que tange à proteção dos direitos dos concorrentes, o Código estabelece que o anúncio publicitário não poderá caracterizar concorrência desleal ${ }^{65}$, denegrimento do produto ou da marca de outra empresa, nem poderá utilizar de forma injustificada a imagem corporativa ou o prestígio de terceiros ${ }^{66}$.

\subsection{CONFLITOS COM DIREITO MARCÁRIO}

Sendo pressuposto da técnica da publicidade comparativa a menção expressa ou implícita ao concorrente comparado, é possível que o exercício da atividade do anunciante eventualmente colida com os direitos de propriedade industrial do concorrente citado no anúncio.

A respeito do direito marcário, ensina-nos o professor Denis Borges Barbosa que:

O registro de marcas resulta na apropriação de uma expressão ou símbolo visual, extraindo do universo das potencialidades semiológicas um determinado complexo significativo, cujo uso torna-se exclusivo ao titular para determinados contextos. Ao designar um produto, mercadoria ou serviço, a marca serve, tradicionalmente, para assinalar a sua origem e,

\footnotetext{
62 "Artigo 32. (...) b. tenha por princípio básico a objetividade na comparação, posto que dados subjetivos, de fundo psicológico ou emocional, não constituem uma base válida de comparação perante o Consumidor".

63 "Artigo 32. (...) c. a comparação alegada ou realizada seja passível de comprovação."

64 "Artigo 32. (...) e. não se estabeleça confusão entre produtos e marcas concorrentes".

65 "Artigo 32. (...) f. não se caracterize concorrência desleal, denegrimento à imagem do produto ou à marca de outra empresa";

66 "Artigo 32. (...) g. não se utilize injustificadamente a imagem corporativa ou o prestígio de terceiros";
} 
em face de outras marcas para itens competitivos, indicar a diferença. Mas, usada como propaganda, além de poder também identificar a origem e as diferenças relativas em face de competidores, deve primordialmente incitar ao consumo ou valorizar a atividade empresarial do titular ${ }^{67}$.

Cabe indagarmos se o mero uso ou citação da marca fora do contexto a que esta se volta originalmente, ou seja, em contexto diverso da identificação do produto ou serviço assinalado, constituiria violação dos direitos de propriedade de seu titular.

Inicialmente, lembramos que o próprio CBARP enquanto permite expressamente a publicidade comparativa, por outro lado veda a infração a direitos marcários de terceiros ${ }^{68}$. O que nos leva a concluir, destarte, que a publicidade comparativa que observa estritamente os requisitos previstos no Código não se traduziria em violação marcária.

Fora do âmbito privado do CONAR, há que se ter em mente que a violação ao direito marcário está expressamente prevista na Lei da Propriedade Industrial (Lei Federal no 9.279 - LPI), em seus artigos $189^{69}$ e $190^{70}$.

Da exegese dos dispositivos legais supramencionados, resulta evidente que o delito ocorre quando há a usurpação da marca de outrem, resultando em confusão para o consumidor.

Não é previsto no tipo penal a figura da "citação", "menção expressa" ou "comparação" de marca registrada sem autorização de seu titular.

A esse respeito, cabe citar caso emblemático, no qual o juízo da $1^{\underline{a}}$ Vara Criminal do Foro Regional de Santo Amaro - SP entendeu que o uso

\footnotetext{
${ }^{67}$ BARBOSA, Denis Borges. Proteção de marcas. Rio de Janeiro: Lumen Juris, 2007, p. 9.

68 "CBARP, Art. 43. O anúncio não poderá infringir as marcas, apelos, conceitos e direitos de terceiros, mesmo aqueles empregados fora do país, reconhecidamente relacionados ou associados a outro anunciante".

69 "Art. 189. Comete crime contra registro de marca quem:

I - reproduz, sem autorização do titular, no todo ou em parte, marca registrada, ou imita-a de modo que possa induzir confusão; ou

II - altera marca registrada de outrem já aposta em produto colocado no mercado.

Pena - detenção, de 3 (três) meses a 1 (um) ano, ou multa".

70 Art. 190. Comete crime contra registro de marca quem importa, exporta, vende, oferece ou expõe à venda, oculta ou tem em estoque:

I - produto assinalado com marca ilicitamente reproduzida ou imitada, de outrem, no todo ou em parte; ou

II - produto de sua indústria ou comércio, contido em vasilhame, recipiente ou embalagem que contenha marca legítima de outrem.

Pena - detenção, de 1 (um) a 3 (três) meses, ou multa.
} 
de marca de concorrente em publicidade comparativa não se subsume ao tipo penal do artigo 189 da $\mathrm{LPI}^{71}$, ou seja, que o emprego da técnica da comparação na publicidade não violaria o direito marcário do concorrente comparado:

(...) O regramento do artigo 32 do CBARP não é incompatível com a Lei de Propriedade Industrial de 1996, sem embargo do entendimento de alguns estudiosos que, com base no artigo 131 de mencionada lei, posicionam-se no sentido de que a simples menção ou citação da marca do concorrente poderia ser capitulada como uso indevido ou desautorizado de marca alheia.

Reza o artigo 131 da Lei de Propriedade Industrial que a proteção de que trata a supra citada lei abrange não apenas o uso da marca em papéis como também em impressos, propaganda e documentos relativos à atividade do titular.

Acompanhamos, contudo, o entendimento de José Carlos Tinoco Soares, no sentido de que mencionado dispositivo pecaria pela total falta de clareza e a simples inclusão da palavra "propaganda" em sua redação não poderia ter o alcance que se pretende dar, sob pena de deturpar a mens legislatoris, o que evitaria qualquer possibilidade de propaganda comparativa.

No caso em apreço, com efeito, não nos parece que possa-se depreender da inicial qualquer alegação de que consumidor estaria sendo enganado ou lesado. A insurgência parece-nos limitar-se ao fato de que a empresa concorrente estaria exibindo, sem a autorização das empresas requerentes, o nome "Duracell" e uma fotografia ou desenho de mencionada pilha, sendo que ambos têm proteção da Lei de Propriedade Industrial.

Ora, se na propaganda não puder ser mencionado o nome do concorrente, nem puder ser exibida qualquer ilustração do produto da outra empresa, a publicidade comparativa restaria inviável e, portanto, indiretamente vedada; e não foi essa, à evidência, a intenção da legislador.

Em momento algum quis a empresa Microlite Sociedade Anônima apropriar-se do nome ou denegrir a marca Duracell, ou ainda, sequer

\footnotetext{
${ }^{71}$ Decisão proferida nos autos do processo no. 0022165-89.2010.8.26.0002, que tramitou perante a 1 - Vara Criminal do Foro Regional de Santo Amaro - SP.
} 
aproveitar-se de sua boa fama no mercado para obter promoção. Embora reconhecidamente agressiva, a propaganda mantem-se dentro do limite da publicidade comparativa.

Assim sendo, entendemos ser atípica a conduta, razão pela qual, eventuais abusos ou prejuízos deverão ser objeto de ação própria na esfera Cível.(...)

O art. 132, IV da LPI prevê expressamente que não constitui violação do direito marcário a citação da marca em "discurso, obra científica ou literária ou qualquer outra publicação, desde que sem conotação comercial e sem prejuízo para seu caráter distintivo". Tal dispositivo "demonstra que a marca é delimitada pela sua função distintiva, não abarcando o uso do signo em si" ${ }^{72}$.

Parte da doutrina que condena o emprego da publicidade comparativa como ferramenta comercial, argumenta que a violação ao direito marcário do concorrente comparado seria intrínseca à própria natureza da comparação ${ }^{7374}$.

Em entendimento oposto, Fábio Ulhoa Coelho ${ }^{75}$ entende pela nãoconfiguração de violação ao direito marcário no contexto da comparação:

No Brasil, a rigor, irregularidade na publicidade comparativa, frente ao direito industrial, somente existe em duas hipóteses: $1^{1}$ ) se, ao mencionar a marca ou marcas da concorrência, o empresário anunciante as imita em seus produtos ou serviços ou, de qualquer forma, induz em confusão os

\footnotetext{
${ }^{72}$ BARBOSA, Pedro Marcos Nunes. Liberdade de Expressão e Signos Distintivos na Internet. Revista Eletrônica do Instituto Brasileiro da Propriedade Intelectual. vol. 03. 2010.

73 "A vedação do uso da marca alheia em publicidade comparativa não se limita à exposição gráfica ou visual dela no anúncio, em qualquer tipo de veículo. As referências verbais à marca alheia na peça comparativa também representam o desrespeito ao direito de propriedade do titular, que poderá se valer de meios coercitivos, obtidos perante o Poder Judiciário, para impedir o anúncio ilícito. A conotação econômica na publicidade atinge o seu texto falado e por isso não deve aceitar a referência à marca alheia". PEREIRA, Marco Antonio Marcondes. A ilicitude da publicidade comparativa. São Paulo: PUC-SP, 2008. 237 p. Tese (Doutorado) - Doutorado em Direito, Pontifícia Universidade Católica de São Paulo, São Paulo, 2008.

${ }^{74}$ Alguns julgados seguem a mesma interpretação e, nesse sentido, citamos: "AGRAVO - AÇÃO DE OBRIGACÃO DE NÃO FAZER - PROPAGANDA COMPARATIVA - USO INDEVIDO DO NOME DO CONCORRENTE EM PUBLICIDADE - ABSTENÇÃO NA PRÁTICA DE ATO QUE IMPORTE NO USO INDEVIDO DO NOME DO AUTOR - POSSIBILIDADE - PRÁTICA DE CONCORRÊNCIA DESLEAL - AGRAVO IMPROVIDO".in Tribunal de Justiça do estado de Mato Grosso do Sul, Agravo de Instrumento ํo. 2010.007716-7, Relator Des. João Maria Lós, julgado em 01/06/2010.

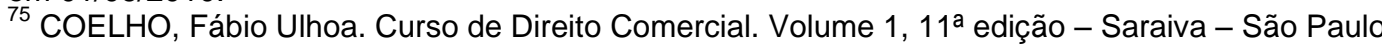
$-2007$
} 
destinatários da mensagem (esta é, inclusive, a conduta tipificada como 'crime contra a marca': LPI, artigo 189, I; $2^{\mathrm{a}}$ ) se a publicidade comparativa pode contribuir para a degenerescência da marca (LPI, artigos 130, III e 131; Cap. 6, item 7.1). Se não ocorrem tais circunstâncias, porém, a comparação não ofende direito de propriedade industrial.

Nesta toada, também Carlos Alberto Bittar ${ }^{76}$ indica que a publicidade será aceita desde que não denigra o concorrente, acrescentando, ainda, a necessidade de observância do princípio da veracidade:

Registre-se, para logo, que não é qualquer alusão ou comparação que se mostra suscetível de integrar o conceito de denigrição. Apenas se consideram como tal as que se apresentem como injustas, oferecendo possibilidade de valoração inexata; ou, por outras palavras, as que levem a descrédito o produto ou atividade do concorrente, ou, ainda, as que se traduzam por inverdades.

Há, ainda, diversos precedentes judiciais no mesmo sentido, dando conta que o uso, citação ou mera referência feito à marca concorrente no contexto da publicidade comparativa não constitui violação ao direito marcário $^{77}$.

\footnotetext{
${ }^{76}$ BITTAR, Carlos Alberto. Teoria e Prática da Concorrência Desleal. São Paulo; Saraiva, 1989, p. 61.

77 Nesse sentido: "Obrigação de não fazer. Concorrência desleal. Propaganda comparativa. Inexistência de ilegalidade da ré em mencionar o nome da autora em publicidade de preços mais baixos, ou de redução se na loja da autora e outra os preços forem mais baratos. Publicidade arrojada que não é mentirosa nem enganosa. llegalidades ausentes. Ausência de Vedação legal. Agravo retido e apelo improvidos." In Tribunal de Justiça do estado de São Paulo, Apelação Cível no 320.565.4/6, Des. Rel. Maia da Cunha, 4aㅡ Câmara de Direito Privado, julgado em 24.11.2005. "EMENTA - OBRIGAÇÃO DE NÃO FAZER - CONCORRÊNCIA DESLEAL - PROPAGANDA COMPARATIVA DE PREÇOS - INEXISTÊNCIA DE ELEMENTO, NA PUBLICIDADE DA RÉ, QUE VENHA A DESABONAR AS MARCAS DE REFERÊNCIA DE PROPRIEDADE DA AUTORA ILEGALIDADE INOCORRENTE - AÇÃO IMPROCEDENTE - RECURSO DESPROVIDO. Voto condutor: 'Nos encartes aqui juntados não se vê, no entanto, qualquer elemento que tenda a desabonar as marcas de referência de propriedade da autora. Limita-se, o material de propaganda, a apresentar quadro comparativo de preços, além de obviamente ressaltar as características dos produtos em promoção. Bem assinalou o MM. Juiz de primeiro grau: 'A mera referência a uma determinada marca, por si só, não pode ser tida como violadora do direito de propriedade de seu titular, desde que respeitados os limites éticos que norteiam as relações comerciais e publicitárias..."' in Tribunal de Justiça do estado de São Paulo, Apelação Cível oㅡ 279.223.4/3-00, Des. Rel. Elliot Akel, $1^{\text {a }}$ Câmara de Direito Privado, julgado em 22.05.2007); "Ação de preceito cominatório c.c. indenização -Abstenção de uso de marca - Citação da marca Novatrex em encarte farmacêutico - Conduta da ré que não pode ser traduzida como uso indevido de marca ou prática de concorrência desleal - Inexistência de afronta ao artigo 132, IV, da Lei 9.279/96 - Propaganda comparativa que vem sendo utilizada em larga escala e que não traz prejuízos à concorrente Instrumento a favor do consumidor e que, no caso dos autos, não denegriu a imagem da autora (mera comparação de preços de medicamento genérico fabricado pelas partes e outros
} 
A tendência dos tribunais é admitir a licitude do uso da técnica da comparação na publicidade ${ }^{78}$ e, na ausência de legislação específica, aplicar os parâmetros e requisitos estabelecidos pelo CONAR.

\subsection{CONFLITOS COM DIREITO AUTORAL}

As peças publicitárias podem gozar de proteção por direito autoral, independentemente da mídia em que são veiculadas ou apresentadas, desde que se revistam de criatividade e seu caráter artístico transcenda o mero anúncio mercanti ${ }^{79}$. Desta forma, obras que se prestem à

laboratórios) - Prática reiteradamente aceita pelo CONAR e que não gera confusão perante os consumidores - Ausência de abuso ou conduta antiética - Improcedência da ação cominatória, afastada a indenização postulada pela demandante (e reiterada na apelação que interpôs) Decisão reformada - Recurso da ré provido, improvido o da autora." in Tribunal de Justiça do estado de São Paulo ,Apelação Cível no 313.198.4/4, Des. Rel. Salles Rossi, 8ª Câmara de Direito Privado, j. em 26.10.2006; "EMENTA - Indenização por danos materiais e morais. Publicação abrangendo propaganda comparativa entre duas marcas de cervejas. Matéria publicada apresenta peculiaridades envolvendo as empresas, além de dar destaque a episódios específicos. Ausência de depreciação da marca da apelante. Sentença se apresenta clara e precisa além de devidamente fundamentada, pois levou em consideração o conteúdo publicado. Suscetibilidade exacerbada da recorrente é manifesta, porém, insuficiente para caracterizar o dano moral pleiteado. Beligerância entre as cervejarias é pública e notória, no entanto, o que fora publicado não afronta a marca da autora e nem a coloca em situação vexatória, uma vez que prevalecem as sutilezas e divergências, sem atingir o patrimônio empresarial do pólo ativo. Apelo desprovido." in Tribunal de Justiça do estado de São Paulo, Apelação Cível no 393.255.4/0-00, Des. Rel. Natan Zelinschi de Arruda, 7ª Câmara de Direito Privado, j. em 28.01.2009;

${ }^{78}$ Nesse sentido: "Os documentos trazidos pelas autoras não comprovam a ocorrência de dano à imagem dos produtos por elas fabricados, nem a utilização indevida das marcas cujos direitos Ihes pertencem. Não se vislumbra a prática de concorrência desleal, pela ré, ao mencionar, na propaganda veiculada, as marcas de cervejas das autoras, visando demonstrar a preferência do consumidor em relação às cervejas participantes, sem que tivessem prévia ciência das marcas experimentadas. A ré comprovou que a metodologia e aplicação do teste ficaram a cargo do Datafolha, bem como a auditoria de suas etapas a cargo da Ernst \& Young, sérias e conceituadas empresas, não sendo crível que estas últimas se prestassem a confirmar resultado que não tivesse sido aquele real e verdadeiro. Não há falar, sem prova concreta, em propaganda mentirosa ou enganosa. A jurisprudência caminha forte no sentido de reconhecer, na propaganda comparativa, técnica proveitosa ao consumidor, desde que observados os requisitos retro mencionados, pelo que não pode ser obstada aquela realizada pela ré, que não resvalou para qualquer das hipóteses de concorrência desleal nem denegriu a imagem dos produtos ou as marcas das autoras." Sentença proferida nos autos do Processo $n^{\circ}$ 2009.217920-7 que tramitou perante a 2 ${ }^{a}$ Vara Cível do Foro Central da Comarca de São Paulo, Juíza Glaucia Lacerda Mansutti).

79 " $A$ atividade publicitária não implica necessariamente a utilização de obras literárias ou artísticas. A grande maioria das mensagens publicitárias é banal, não se suscitando, portanto, problemas de direito autoral. Mas podem utilizar-se obras literárias ou artísticas nesta atividade. Um texto laudatório dum bem pode ser literário. Uma fotografia pode ser artística. Tratando-se de obras utilitárias, haverá que ter presente a exigência particular de criatividade, que se exprime pela imposição da originalidade. A mensagem publicitária só será assim protegida quando o seu caráter literário ou artístico ultrapasse o caráter pragmático do objeto a que estiver sobreposta". 
publicidade podem ser protegidas, sejam obras audiovisuais, cartazes, fotografias, textos, obras musicais (jingles), etc ${ }^{80}$.

Uma peça publicitária pode envolver o trabalho criativo de diversos profissionais, como roteirista, diretor, diretor de produção, diretor de fotografia, diretor de arte, etc. Da soma dos esforços e criações coletivas resultará uma obra final, da qual a agência que criou a campanha será titular dos direitos patrimoniais de autor ${ }^{818283 .}$

Não obstante, cabe aos criadores publicitários o direito moral sobre suas criações, na lição de CARLOS ALBERTO BITTAR ${ }^{84}$ :

ASCENSÃO, José de Oliveira. Direito Autoral. Direito Autoral. 2. ed., ref. e ampl. Rio de Janeiro: Renovar, 1997. p. 451.

80 "A obra publicitária é o anúncio em si, veiculado sob a forma gráfica em jornais, revistas e outdoors, sob a forma exclusivamente sonora para veiculação em rádio (spot), ou sob a forma audiovisual para exibição em TV ou cinema. Obra publicitária, protegida autoralmente, não se confunde com campanha publicitária, sendo apenas parte dela. A proteção autoral se dá ao filme publicitário como obra autônoma, independente do contexto geral da campanha, do mesmo modo como se dá com os demais tipos de obra audiovisual". ABRẢO, Eliane Yachouh. Direitos de autor e direitos conexos. São Paulo: Editora do Brasil, 2002. p. 111

81 De acordo com o art. 17, $\S 2^{\circ}$ da Lei de Direitos Autorais "cabe ao organizador a titularidade dos direitos patrimoniais sobre o conjunto da obra coletiva".

82 "Muito frequentemente também, a elaboração da mensagem publicitária origina uma obra coletiva. Isso acontece quando, nos termos gerais, a obra de conjunto pressupuser uma e empresa e não puder ser imputada a uma autoria singular. A complexidade da mensagem publicitária implica que muitas vezes as contribuições individuais se fundam numa obra de conjunto que não dominam, como elementos parcelares. A obra de conjunto é então da empresa. Os contributos individuais não deixam de ser por si obras. Sobre elas recaem direitos autônomos. Mas o exercício só a estes pode respeitar, e em termos que não prejudiquem a exploração da obra de conjunto". ASCENSÃO, José de Oliveira. Direito Autoral. 2. ed., ref. e ampl. Rio de Janeiro: Renovar, 1997. p. 453.

${ }^{83}$ Sobre a titularidade da peça publicitária audiovisual: " Quem é o titular autoral da obra audiovisual publicitária? Produtores, agência, anunciante? Diferentemente do que ocorre com a obra cinematográfica, a obra publicitária é aquela criada ou roteirizada pela agência, dirigida pela produtora (de filmes publicitários) e financiada pelo anunciante, que Ihe imprime os contornos.

$O$ decreto $n^{\circ} 57.690$ de $1^{\circ}$ de fevereiro de 1966, que regulamenta a atividade publicitária no Brasil, em complementação à lei 4.680, de 18/6/1965, em seu art. 6oㅡ, define agência de propaganda como sendo a pessoa jurídica especializada nos métodos, na arte e na técnica publicitária, que, através de profissionais a seu serviço, estuda, concebe, executa e distribui propaganda aos Veículos de Divulgação, por ordem e conta de clientes anunciantes, com o objetivo de promover a venda de mercadorias, produtos e serviços, difundir idéias ou informar o público a respeito de organizações ou instituições a que servem. Portanto, a agência concebe a propaganda agindo por ordem e conta do cliente, o anunciante. Nesse mister, a agência encomenda a obra audiovisual ao produtor, fornecendo-Ihe roteiro e interferindo diretamente em sua confecção, sempre por encomenda do anunciante. De outro lado, a lei autoral declara autor de obra coletiva quem Ihe toma a iniciativa, organiza-a, por ela se responsabiliza e que a publica sob seu nome e marca (art. 5o, VIII, h, lei 9.610/98). Qual a marca a que se refere o legislador autoral? Certamente não a marca, de produto ou serviço, divulgada com o conteúdo da obra publicitária, isto é, a marca de produto ou serviço do anunciante, mas da marca que identifica o próprio anunciante.

Dentro da óptica do legislador autoral, pois, a titularidade da obra audiovisual publicitária pertencerá em co-autoria ao produtor de comerciais, que desempenha o papel de diretor da obra audiovisual publicitária, a que, incumbirá também o exercício dos direitos morais, intransferíveis, e à agência que tomou a iniciativa dela, como autora do argumento (obra literária), e como aquela em cujo nome a obra é publicada." ABRÃO, Eliane Yachouh. Direitos de autor e direitos conexos. São Paulo: Editora do Brasil, 2002. p. 111

${ }^{84}$ BITTAR, Carlos Alberto. Contornos atuais do direito do autor, $2^{\mathrm{a}}$ Ed., revista, atualizada e ampliada. São Paulo: Revista dos Tribunais, 1999. 
São, pois, titulares de direitos na publicidade: a) os criadores, os que elaboram obra individualizada ou individualizável (nesse rol se incluem os escritores, poetas, compositores, atores, intérpretes e outros); b)a agência, na hipótese de obra coletiva (ou seja, elaborada através da conjugação da contribuição de diversos criadores, mas sob a direção da agência, de modo que não se possa, na obra final, individualizar a colaboração de cada qual); c) a produtora, nas mesmas condições da agência (seja de fonograma, seja de filme).

Assinale-se, outrossim, que, em qualquer caso, à agência (ou à produtora) cabem os direitos sobre a obra final nela produzida (o anúncio em seu conjunto, o fonograma como tal, o filme, e assim por diante), que coexistem com os direitos dos autores de obra individualizada ou individualizável que a integre (exemplo: o autor do texto, do desenho, da música).

Não apresenta maiores dificuldades a questão da reprodução indevida de obra publicitária, sendo certo que a Lei 9.610 (Lei de Direitos Autorais) veda tal prática. Da mesma forma, o CBARP, em sua seção 12 , estabelece a proteção ao Direito Autoral como princípio a ser seguido na atividade publicitária ${ }^{85}$.

A análise torna-se um pouco mais complexa nos casos envolvendo publicidade comparativa, como em anúncios que fazem alusão à peças publicitárias do concorrente comparado, ou, ainda, fazem paródia ou paráfrase destas.

Há que se lembrar que as idéias não são protegidas por direito autoral $^{86} \mathrm{e}$, desta forma, a mera alusão à peça de concorrente ou uso de

\footnotetext{
${ }^{85}$ Artigo 38. Em toda a atividade publicitária serão respeitados os direitos autorais nela envolvidos, inclusive os dos intérpretes e os de reprodução.

Artigo 39. O anúncio não utilizará música de fundo, "vinhetas", ou trechos de composições de autores nacionais ou estrangeiros sem o devido respeito aos respectivos direitos autorais, a não ser no caso de músicas que sejam ou se tenham tornado de domínio público, de acordo com a legislação específica, respeitados os direitos de gravação.

Artigo 40. É condenado o uso desrespeitoso da música folclórica, dos folguedos e temas populares que constituem parte integrante do patrimônio cultural do país.

Artigo 41. Este Código protege a criatividade e a originalidade e condena o anúncio que tenha por base o plágio ou imitação, ressalvados os casos em que a imitação é comprovadamente um deliberado e evidente artifício criativo".

${ }^{86}$ Lei 9.610 (Lei de Direitos Autorais): "Art. 8№̃o são objeto de proteção como direitos autorais de que trata esta Lei: I - as idéias, procedimentos normativos, sistemas, métodos, projetos ou conceitos matemáticos como tais; (...)".
} 
conceito artístico semelhante não importaria em violação de direitos autorais $^{8788}$.

Como bem leciona José de Oliveira Ascensão "As idéias, uma vez concebidas, são patrimônio comum da humanidade. É inimaginável um sistema em que as idéias de alguém fossem restritas na sua utilização"89.

Ainda, no que se refere às paródias, a Lei de Direitos Autorais as autoriza expressamente, desde que não impliquem em descrédito desproporcional da obra original ${ }^{90}$.

A respeito das paródias, ensina José de Oliveira Ascensão ${ }^{91}$ :

É muito interessante o que se passa com as paródias. É lícito parodiar uma obra anterior, e assim acontece com grande freqüência em réplicas de representações dramáticas ou de filmes; os programas cômicos de televisão, ou o teatro ligeiro, vivem disto em grande parte. Mas a paródia não pode limitar-se ao mero aproveitamento do tema anterior. Tem de se apreciar o seu próprio grau de criatividade, para julgar daquilo a que se chama 'o tratamento antitético do tema'. (...) Também as paráfrases não representam violação de direito de autor, por determinação expressa do art. 50. (...) Exige ainda a lei que a paródia ou a paráfrase não impliquem descrédito à obra originária. Obviamente, foi a consideração da paródia que impôs esta segunda limitação. O não implicar descrédito não condiciona porém propriamente a liberdade da utilização, mas a licitude da obra criada. Se não satisfizer este segundo requisito ela poderá ser retirada da circulação.

\footnotetext{
87 "A ideia-base de uma campanha ou mensagem publicitária pode ser muito valiosa. Por isso se compreende que se tenha buscado a sua proteção. Mas a idéia não é uma obra, é um esquema para a ação. Nunca poderá aspirar a ter tutela pelo Direito Autoral". ASCENSÃO, José de Oliveira. Direito Autoral. 2. ed., ref. e ampl. Rio de Janeiro: Renovar, 1997. p. 452.

${ }_{88}$ "A idéia publicitária, de uma campanha ou de um comercial, é tratada pela lei autoral como toda idéia: é inapropriável. O Judiciário já teve oportunidade de manifestar-se sobre o assunto e o reitoerou de modo cristalino: 'Direito Autoral. Não merece proteção legal a idéia publicitária, senão a sua forma de expressão. Não comprovado o acesso à obra original; ausente o interesse econômico; e se não há identidade na forma de expressão, não está caracterizado o plágio.' (AP. Cv. 1989.001.05724, re. 10/7/1990, 2ª Câmara Cível, Rel. Des. Murillo Fabregas.)". ABRÃO, Eliane Yachouh. Direitos de autor e direitos conexos. São Paulo: Editora do Brasil, 2002. p. 112.

${ }^{89}$ ASCENSÃO, José de Oliveira. Direito Autoral. 2. ed., ref. e ampl. Rio de Janeiro: Renovar, 1997. p. 28.

${ }^{50}$ Lei 9.610 (Lei de Direitos Autorais): "Art. 47. São livres as paráfrases e paródias que não forem verdadeiras reproduções da obra originária nem Ihe implicarem descrédito".

${ }^{91}$ ASCENSÃO, José de Oliveira. Direito Autoral. 2. ed., ref. e ampl. Rio de Janeiro: Renovar, 1997. p. $65-66$.
} 
Desta forma, conclui-se que a publicidade comparativa que faz alusão à idéia ou tema central de campanha concorrente ou parodia peça publicitária do concorrente comparado não estaria violando seu direito autoral, desde que a paródia imprimisse grau de criatividade à peça nova e não importasse em descrédito desproporcional da obra original. 


\section{O DIREITO À INFORMAÇÃO NA SEARA CONSUMERISTA}

O Código de Defesa do Consumidor (CDC) institui como direito básico do consumidor o acesso à informação adequada e clara sobre os diferentes produtos e serviços disponíveis para consumo no mercado ${ }^{92}$.

Assim, o CDC estabelece que 0 consumidor deve ser "adequadamente informado sobre os componentes do produto e serviços (orçamento) para não ter surpresa desagradável e danosa por ocasião do uso ou da entrega do trabalho encomendado" "93.

$\mathrm{O}$ acesso a informações precisas e transparentes sobre produtos e serviços é fundamental para promover o equilíbrio nas relações de consumo ${ }^{94}$, pois permite que os consumidores tomem suas decisões de compra de forma consciente ${ }^{95}$.

Destarte, cabe afirmarmos que "um dos princípios mais relevantes assegurados ao consumidor, é, sem dúvida alguma, o da informação clara e precisa (art. $6^{\circ}$, III) do produto ou serviço fornecido" ${ }^{\prime 96}$.

A respeito da necessidade de informar claramente o consumidor, assim se posiciona Paulo Luiz Netto Lôbo:

A adequação diz com os meios de informação utilizados e com respectivo conteúdo. Os meios devem ser compatíveis com o produto ou o serviço determinados e o consumidor destinatário típico. Os signos empregados

\footnotetext{
92 "Art. 6ㅇ São direitos básicos do consumidor: (...) III - a informação adequada e clara sobre os diferentes produtos e serviços, com especificação correta de quantidade, características, composição, qualidade e preço, bem como sobre os riscos que apresentem";

93 ZULIANI, Ênio Santarelli. Direitos básicos do consumidor. In SILVA, Regina Beatriz Tavares da (coord.), Responsabilidade Civil nas relações de consumo. São Paulo: Saraiva, 2009. p. 22.

94 "Assim, se há o paradigma da boa-fé nas relações entre iguais (dois empresários) e há o dever de informar, é claro que a informação entre experts deve ser mais branda, mesmo que leal, pois são dois profissionais e especialistas. Já a informação do expert em relação em relação ao consumidor é um dever qualificado, há que se pressupor que ele é um leigo, há dever de esclarecer, aconselhar, explicar dados que seriam banais e pressupostos entre dois empresários, mas não entre um profissional e um leigo. Quem usar o mesmo paradigma e o Código Civil de 2002 na relação entre diferentes estará violando o valor (Wert) constitucional de proteger os consumidores de forma especial, mesmo que invoque a boa-fé para fazê-lo! Daí a importância da idéia de diálogo das fontes" in MARQUES, Claudia Lima. A nova crise do contrato: Estudos sobre a nova teoria contratual. Ed. Revista dos Tribunais; São Paulo, 2007, p. 86.

95 "A massificação do consumo, por outro lado, agravou o distanciamento da informação suficiente. Nesse quadro, é compreensível que o direito avance para tornar o dever de informar um dos esteios eficazes do sistema de proteção"in LÔBO, Paulo Luiz Netto. Teoria Geral das Obrigações. São Paulo: Editora Saraiva, 2005, p. 96.

${ }^{96}$ ZULIANI, Ênio Santarelli. Direitos básicos do consumidor. In SILVA, Regina Beatriz Tavares da (coord.), Responsabilidade Civil nas relações de consumo. São Paulo: Saraiva, 2009. p. 23.
} 
(imagens, palavras, sons) devem ser claros e precisos, estimulantes do conhecimento e da compreensão. No caso de produtos, a informação deve referir-se à composição, aos riscos, à periculosidade. (...) A legislação de proteção do consumidor destina à linguagem empregada na informação especial cuidado. Em primeiro lugar, o idioma será o vernáculo. Em segundo lugar, os termos empregados hão de ser compatíveis com o consumidor típico destinatário. Em terceiro lugar, toda informação necessária que envolva riscos ou ônus que devem ser suportados pelo consumidor será destacada, de modo a que "saltem aos olhos"97.

Indo além na análise da necessidade de esclarecer o consumidor, Guilherme Magalhães Martins ${ }^{98}$ afirma que a ausência de dados essenciais sobre o produto ou serviço o tornaria defeituoso

No tocante à aferição do defeito no consumo, um dos principais campos é o da informação, cuja prestação consiste em dever do fornecedor e cuja falta ou mera inadequação transforma o produto, ainda que intrinsecamente bom, em defeituoso.

Cabe citarmos ainda, como conseqüência do princípio da informação, que o artigo 30 do $\mathrm{CDC}^{99}$ estabelece que o conteúdo do anúncio publicitário vincula o anunciante à oferta anunciada e passa a integrar o contrato ${ }^{100}$.

Entretanto, não basta que o fornecedor preste informações a respeito do produto ou serviço, como estudaremos a seguir ele deverá fazê-lo de forma transparente, completa e verídica.

\footnotetext{
97 LÔBO, Paulo Luiz Netto. Teoria Geral das Obrigações. São Paulo: Editora Saraiva, 2005, p. 97.

98 MARTINS, Guilherme Magalhães. Responsabilidade Civil por Acidente de Consumo na Internet. Editora Revista dos Tribunais; São Paulo; 2008, p. 121.

99 "Art. 30. Toda informação ou publicidade, suficientemente precisa, veiculada por qualquer forma ou meio de comunicação com relação a produtos e serviços oferecidos ou apresentados, obriga o fornecedor que a fizer veicular ou dela se utilizar e integra o contrato que vier a ser celebrado".

100 "o conteúdo do reclame publicitário, quando suficientemente preciso, vincule o fornecedor a cumprir exatamente o que se propôs a anunciar, sendo a oferta elemento implícito do pacto contratual estabelecido perante o consumidor".
} 


\subsection{O PRINCÍPIO DA TRANSPARÊNCIA MÁXIMA NAS RELAÇÕES DE CONSUMO}

A transparência máxima nas relações de consumo, no que tange à publicidade, inicia com a própria caracterização inequívoca desta. De acordo com o artigo 36 do $\mathrm{CDC}^{101}$, o anúncio publicitário deverá ser ostensiva $^{102}$ e facilmente identificável pelo consumidor como tal, não podendo se travestir em notícias jornalísticas, ou informes oficiais.

Tal determinação encontra eco, ainda, no CBARP, que estabelece o mesmo em seu artigo $28^{103}$. O artigo 30 do CBARP ainda determina que "peça jornalística sob a forma de reportagem, artigo, nota, texto-legenda ou qualquer outra que se veicule mediante pagamento, deve ser apropriadamente identificada para que se distinga das matérias editoriais e não confunda o Consumidor".

Além de apresentar claramente a publicidade, Ênio Santarelli Zuliani informa que $o$ anunciante tem ainda os deveres de:

(...) transmitir informações completas e adequadas, de não supervalorizar virtudes ou esconder problemas, de não esconder o preço, de não empregar subterfúgios e truques cinematográficos ou fotográficos para criar uma falsa percepção da realidade.

O CDC $^{104}$ e o CBARP $^{105}$ determinam ainda que os dados veiculados em anúncios publicitários devem ser comprovados ou comprováveis. Assim, poderá ser determinado que o anunciante, em sede de

\footnotetext{
101 "Art. 36. A publicidade deve ser veiculada de tal forma que o consumidor, fácil e imediatamente, a identifique como tal".

${ }_{102}$ "CBARP, Artigo 9": A atividade publicitária de que trata este Código será sempre ostensiva. $\S 10-A$ alusão à marca de produto ou serviço, razão social do anunciante ou emprego de elementos reconhecidamente a ele associados atende ao princípio da ostensividade". $\S 20-0$ "teaser", assim entendida a mensagem que visa a criar expectativa ou curiosidade no público, poderá prescindir da identificação do anunciante, do produto ou do serviço".

103 "Artigo 28. O anúncio deve ser claramente distinguido como tal, seja qual for a sua forma ou meio de veiculação".

104 "Art. 36 Parágrafo único. O fornecedor, na publicidade de seus produtos ou serviços, manterá, em seu poder, para informação dos legítimos interessados, os dados fáticos, técnicos e científicos que dão sustentação à mensagem".

105 "Artigo 27. §1- Descrições. No anúncio, todas as descrições, alegações e comparações que se relacionem com fatos ou dados objetivos devem ser comprobatórias, cabendo aos Anunciantes e Agências fornecer as comprovações, quando solicitadas".
} 
representação ética perante o CONAR ou judicialmente, apresente provas acerca dos dados e alegações apresentados em seu anúncio ${ }^{106}$.

\subsection{O PRINCÍPIO DA VERACIDADE E DA NÃO-ABUSIVIDADE NA PUBLICIDADE}

Ainda no tocante ao tratamento dado às informações veiculadas aos consumidores através da publicidade, o CDC veda a utilização de qualquer tipo de publicidade que seja enganosa ou abusiva ${ }^{107}$.

Acerca da publicidade enganosa, o CDC a define como:

qualquer modalidade de informação ou comunicação de caráter publicitário, inteira ou parcialmente falsa, ou, por qualquer outro modo, mesmo por omissão, capaz de induzir em erro o consumidor a respeito da natureza, características, qualidade, quantidade, propriedades, origem, preço e quaisquer outros dados sobre produtos e serviços (Art. $\left.37, \S 1^{\circ}\right)$.

O CBARP além de também vedar qualquer tipo de publicidade enganosa, de acordo com o que determina seu artigo 10108, estabelece em seu artigo 27 diversos parâmetros que devem ser seguidos pelos anunciantes a fim de apresentar informações corretas, completas e verdadeiras $^{109}$.

\footnotetext{
106 "No comercial que vem de ser apreciado, pretende-se que o produto "Thunder" só por si substitui e exerce as funções (de limpeza, desinfecção, desodorização) que seriam atributo, individualizado, de cada um dos produtos concorrentes. A frase final atesta bem esta conclusão. Posta em dúvida a veracidade desta afirmação pelo Autor, na representação, incumbia ao denunciado o ônus de comprová-la, com documentos que atestassem a verdade científica desta afirmação. Não nos parece que uma pesquisa encomendada pela denunciada e levada a efeito junto a donas de casa, por empresa especializada, tenha o mesmo valor. Conseqüentemente, em nossa opinião, a propaganda é, neste ponto, enganosa, violando os arts. $1^{\circ}$ e 27 do Código de Ética". Decisão da Representação no 058/89 do CONAR.

107 "Art. 37. É proibida toda publicidade enganosa ou abusiva".

108 "Artigo 1‥ Todo anúncio deve ser respeitador e conformar-se às leis do país; deve, ainda, ser honesto e verdadeiro".

109 "CBARP, Artigo 27. O anúncio deve conter uma apresentação verdadeira do produto oferecido, conforme disposto nos artigos seguintes desta Seção, onde estão enumerados alguns aspectos que merecem especial atenção. § 1ํ-Descrições: No anúncio, todas as descrições, alegações e comparações que se relacionem com fatos ou dados objetivos devem ser comprobatórias, cabendo aos Anunciantes e Agências fornecer as comprovações, quando solicitadas; $\S 2^{\circ}$ -
} 
A publicidade enganosa se caracteriza por conter informações falsas, que possam trazer uma falsa percepção da realidade e induzir o consumidor ao erro. Fábio Ulhoa Coelho ${ }^{110}$ caracteriza a publicidade enganosa de acordo com os critérios abaixo:

\author{
O decisivo é investigar se o conteúdo transmitido é suscetível de induzir \\ em erro o consumidor do fornecimento em programação. Se, a partir da \\ mensagem, se constata que ele pode ser levado a tomar por verdadeira a
}

Alegações: O anúncio não deverá conter informação de texto ou apresentação visual que direta ou indiretamente, por implicação, omissão, exagero ou ambigüidade, leve o Consumidor a engano quanto ao produto anunciado, quanto ao Anunciante ou seus concorrentes, nem tampouco quanto à: a.natureza do produto (natural ou artificial); b. procedência (nacional ou estrangeira); $c$. composição; $d$. finalidade; $\S 3^{\circ}$ - Valor, Preço, Condições: $O$ anúncio deverá ser claro quanto a: a. valor ou preço total a ser pago pelo produto, evitando comparações irrealistas ou exageradas com outros produtos ou outros preços: alegada a sua redução, o Anunciante deverá poder comprová-la mediante anúncio ou documento que evidencie o preço anterior; b. entrada, prestações, peculiaridades do crédito, taxas ou despesas previstas nas operações a prazo; c. condições de entrega, troca ou eventual reposição do produto; $d$. condições e limitações da garantia oferecida. $\S$ 4- - Uso da Palavra "Grátis": a. O uso da palavra "grátis" ou expressão de idêntico significado só será admitido no anúncio quando não houver realmente nenhum custo para o Consumidor com relação ao prometido gratuitamente; $b$. nos casos que envolverem pagamento de qualquer quantia ou despesas postais, de frete ou de entrega ou, ainda, algum imposto, é indispensável que o Consumidor seja esclarecido. $\$ 5^{\circ}$ - Uso de Expressões Vendedoras: O uso de expressões como "direto do fabricante", "preço de atacado", "sem entrada" e outras de igual teor não devem levar o consumidor a engano e só serão admitidas quando o Anunciante ou a Agência puderem comprovar a alegação. $\$ 6^{\circ}$ - Nomenclatura, Linguagem, "Clima": a. O anúncio adotará o vernáculo gramaticalmente correto, limitando o uso de gíria e de palavras e expressões estrangeiras, salvo quando absolutamente necessárias para transmitir a informação ou o "clima" pretendido. Todavia, esta recomendação não invalida certos conceitos universalmente adotados na criação dos anúncios e campanhas. O primeiro deles é que a publicidade não se faz apenas com fatos e idéias, mas também com palavras e imagens; logo, as liberdades semânticas da criação publicitária são fundamentais. O segundo é que a publicidade, para se comunicar com o público, tem que fazer uso daquela linguagem que o poeta já qualificou como " Língua errada do povo / Língua certa do povo / Porque ele é que fala gostoso / O português no Brasil"; b. na publicidade veiculada pelo Rádio e pela Televisão, devem os Anunciantes, Agências e Veículos zelar pela boa pronúncia da língua portuguesa, evitando agravar os vícios de prosódia que tanto já estão contribuindo para desfigurar o legado que recebemos de nossos antepassados; c. todo anúncio deve ser criado em função do contexto sociocultural brasileiro, limitando-se o mais possível a utilização ou transposição de contextos culturais estrangeiros; $d$. o anúncio não utilizará o calão; $e$. nas descrições técnicas do produto, o anúncio adotará a nomenclatura oficial do setor respectivo e, sempre que possível, seguirá os preceitos e as diretrizes da Associação Brasileira de Normas Técnicas - ABNT e do Instituto Nacional de Metrologia, Normalização e Qualidade Industrial INMETRO. $\S 7^{\circ}$ - Pesquisas e Estatísticas: a. o anúncio não se referirá a pesquisa ou estatística que não tenha fonte identificável e responsável; $b$. o uso de dados parciais de pesquisa ou estatística não deve levar a conclusões distorcidas ou opostas àquelas a que se chegaria pelo exame do total da referência. $\S 8^{\circ}$ - Informação Científica: $O$ anúncio só utilizará informação científica pertinente e defensável, expressa de forma clara até para leigos. $\S$ 9o - Testemunhais: a. O anúncio abrigará apenas depoimentos personalizados e genuínos, ligados à experiência passada ou presente de quem presta o depoimento, ou daquele a quem o depoente personificar; b. o testemunho utilizado deve ser sempre comprovável; c. quando se usam modelos sem personalização, permite-se o depoimento como "licença publicitária" que, em nenhuma hipótese, se procurará confundir com um testemunhal; $d$. o uso de modelos trajados com uniformes, fardas ou vestimentas características de uma profissão não deverá induzir o Consumidor a erro e será sempre limitado pelas normas éticas da profissão retratada; e. o uso de sósias depende de autorização da pessoa retratada ou imitada e não deverá induzir a confusão".

${ }_{110}$ COELHO, Fábio Ulhoa. A publicidade enganosa no Código de Defesa do Consumidor. In Revista do Direito do Consumidor. . São Paulo: Editora Revista dos Tribunais. Outubro/Dezembro,1993. p.71 
informação falsa, então caracteriza-se a publicidade enganosa. Pelo contrário, se, a partir ainda da mensagem, se constata que o consumidor não tem como tomar por verdadeira a informação falsa, então, a publicidade é lícita, apesar de conter falsidades.

Importante notarmos que a publicidade pode ser enganosa por ato comissivo do anunciante, quando este dispuser dados errôneos acerca do bem ou serviço ou, ainda, por omissão do fornecedor, quando este ocultar dados essenciais sobre o produto ou serviço ${ }^{111}$ em seu material publicitário.

Todos os dados e alegações apresentados por um anunciante devem ser totalmente verdadeiros, tendo em mente que "a publicidade não verdadeira, ou parcialmente verdadeira, é considerada enganosa, e o direito do consumidor destina especial atenção a suas conseqüências" ${ }^{112}$. O CDC traz ainda um rol exemplificativo ${ }^{113}$ do que seria considerado publicidade abusiva, no $2^{\circ}$ do seu artigo 37 :

$\S 2^{\circ}$ É abusiva, dentre outras a publicidade discriminatória de qualquer natureza, a que incite à violência, explore o medo ou a superstição, se aproveite da deficiência de julgamento e experiência da criança, desrespeita valores ambientais, ou que seja capaz de induzir o consumidor a se comportar de forma prejudicial ou perigosa à sua saúde ou segurança.

O CBARP também veda a publicidade abusiva e apresenta, nos seus artigos 19 a $26^{114}$, um rol mais extensivo do que o proposto pelo CDC.

\footnotetext{
111 "CDC, Art. 38. O ônus da prova da veracidade e correção da informação ou comunicação publicitária cabe a quem as patrocina".

112 LÔBO, Paulo Luiz Netto. Teoria Geral das Obrigações. São Paulo: Editora Saraiva, 2005, p. 98.

113 "A diversidade de formas abusivas torna de difícil sistematização o conteúdo do texto legal, sendo preferível pelo menos a priori, a análise de acordo com a técnica de catálogo, adotada pela lei, e que permitirá interferir o seu propósito protetivo. Como se trata de número aberto, ao final serão acrescentados dois tópicos: o primeiro, sobre outras formas abusivas, não-explicitadas, comportando uma investigação sobre uma cláusula geral de abusividade; e o segundo sobre formas não-abusivas, à luz da lei.". PASQUALOTTO, Adalberto. Os Efeitos Obrigacionais da Publicidade o Código de Defesa do Consumidor. São Paulo: Editora Revista dos Tribunais. 1997. p.127-128.

114 "SEÇÃO 1 - Respeitabilidade. Artigo 19: Toda atividade publicitária deve caracterizar-se pelo respeito à dignidade da pessoa humana, à intimidade, ao interesse social, às instituições $e$ símbolos nacionais, às autoridades constituídas e ao núcleo familiar; Artigo 20 :
} 
Para ZULIANI115 "publicidade abusiva é a que violenta os valores fundamentais da sociedade, tutelados ou não no ordenamento jurídico".

Para Rosângela Amatrudo, o legislador do Código de Defesa do Consumidor não esclareceu uma definição para o que seja abusividade. De todo modo, a autora remete a abusividade à inobservância de valores sociais:

Consideramos que tal dificuldade apresentada pela doutrina ocorre, pois, ao contrário do que acontece com a publicidade enganosa, a publicidade abusiva faz parte da seara dos valores sociais. Embora o legislador não tenha precisamente definido o que é publicidade abusiva, fica clara sua intenção, ao querer proteger valores sociais, enumerando-os a título de exemplo $^{116}$.

Os princípios da veracidade e da não-abusividade são desdobramentos ${ }^{117}$ do princípio da boa-fé ${ }^{118}$, que norteia não apenas as relações de consumo, mas também as relações contratuais em geral ${ }^{119}$.

\footnotetext{
Nenhum anúncio deve favorecer ou estimular qualquer espécie de ofensa ou discriminação racial, social, política, religiosa ou de nacionalidade; Artigo 21 . Os anúncios não devem conter nada que possa induzir a atividades criminosas ou ilegais - ou que pareça favorecer, enaltecer ou estimular tais atividades. SEÇÃO 2 - Decência Artigo 22: Os anúncios não devem conter afirmações ou apresentações visuais ou auditivas que ofendam os padrões de decência que prevaleçam entre aqueles que a publicidade poderá atingir. SEÇÃO 3 - Honestidade Artigo 23: Os anúncios devem ser realizados de forma a não abusar da confiança do consumidor, não explorar sua falta de experiência ou de conhecimento e não se beneficiar de sua credulidade. SEÇÃO 4 - Medo, Superstição, Violência Artigo 24: Os anúncios não devem apoiar-se no medo sem que haja motivo socialmente relevante ou razão plausível. Artigo 25: Os anúncios não devem explorar qualquer espécie de superstição. Artigo 26. Os anúncios não devem conter nada que possa conduzir à violência".

115 ZULIANI, Ênio Santarelli. Direitos básicos do consumidor. In SILVA, Regina Beatriz Tavares da (coord.), Responsabilidade Civil nas relações de consumo. São Paulo: Saraiva, 2009. p. 27.

16 AMATRUDO, Rosangela. Publicidade Abusiva. In: Revista de Direito do Consumidor. n.52.outubro-dezembro. São Paulo: Editora Revista dos Tribunais. 2004. p.204

117 "Do dever de atuar segundo a boa-fé derivam três deveres específicos: a) os deveres de proteção, que determinam que as partes devem evitar qualquer atuação suscetível de causar danos à outra parte, sejam eles pessoais ou patrimoniais; b) os deveres de informação, em especial quanto às circunstâncias que possam ser relevantes para a formação do consenso da outra parte e com especial intensidade quando uma das partes se apresenta como mais fraca; c) deveres de lealdade, para evitar comportamentos que traduzam deslealdade para com a outra parte" in LÔBO, Paulo Luiz Netto. Teoria Geral das Obrigações. São Paulo: Editora Saraiva, 2005, p. 81.

${ }_{118}$ "Da análise desses princípios do direito publicitário, podemos identificar um princípio maior, fonte de inspiração comum a todos eles, o da probidade e da boa-fé lealdade (Treu und Glauben), que orienta toda a construção jurídica do Código de Defesa do Consumidor, a exemplo do que também prevaleceu no momento da elaboração do Código Civil de 2002". DA SILVA, Regina Beatriz Tavares da e POLETTO, Carlos Eduardo Minozzo. Responsabilidade Civil pela Publicidade. In SILVA, Regina Beatriz Tavares da (coord.), Responsabilidade Civil nas relações de consumo. São Paulo: Saraiva, 2009. p. 402.

119 "Conforme referido acima, a boa-fé objetiva atua como eixo comum de diversas teorias que se vêm difundindo seja na formulação de critérios de interpretação-integração do contrato, seja para
} 
No que tange às relações de consumo, onde há disparidade de armas entre o consumidor e o fornecedor, o princípio da boa-fé deve ser observado com maior intensidade e restrição, visando a corrigir a natural vulnerabilidade do consumidor, com bem leciona Paulo Luiz Netto Lôbo $^{120}$ :

Quanto maior o peso da horizontalidade, maior o espaço da autonomia privada, e, conseqüentemente, menor a intensidade da aplicação da boafé. Ao contrário, quanto mais diminuto o espaço de autonomia, maior a intensidade da boa-fé. Os graus de intensidade, para ponderação do julgador, decorrem também do fato de a boa-fé não indicar a conduta devida (o que deve ser prestado), mas o seu "como", isto é, a maneira pela qual a conduta deve ser desenvolvida. Cita como exemplo de assimetria ou verticalidade a relação entre consumidor e fornecedor, que impõe mais intensidade da boa-fé; acrescentamos: em todas as hipóteses de presunção legal de vulnerabilidade do contratante, a exemplo do aderente.

Concluímos, desta forma, que, para ser lícita e aceitável, toda forma de publicidade deve obedecer ao princípio geral da boa-fé, presente tanto no Código Civil quanto no Código de Defesa do Consumidor, bem como observar os princípios da transparência máxima nas relações de consumo, da veracidade e da não-abusividade da publicidade, contemplados na legislação consumerista e nas regras éticas do CONAR.

\footnotetext{
impor a criação de deveres no contexto da relação contratual, ou para limitar o exercício de direitos. Em comum, as diversas ramificações da boa-fé têm um sentido e um fim éticos, segundo os quais a relação contratual deve ser compreendida como uma relação de cooperação, impondose um dever de recíproca colaboração entre os contratantes em vista da realização do programa econômico estabelecido no contrato. (...) Segundo o autor, à luz da Constituição o princípio da boa-fé não há de resultar necessariamente em vantagem para o consumidor, podendo mesmo justificar o seu desfavorecimento: “... a boa-fé não serve tão-só para a defesa do débil (parte mais fraca na relação obrigacional), mas também atua como fundamento para orientar interpretação garantida da ordem econômica, compatibilizando interesses contraditórios onde, eventualmente, poderá prevalecer o interesse contrário até mesmo ao do consumidor, se o interesse social prevalente assim o determinar" in NEGREIROS, Teresa. Teoria do Contrato, Novos Paradigmas. Editora Renovar, Rio de Janeiro, 2006, p. 130.

${ }_{120}$ LÔBO, Paulo Luiz Netto. Teoria Geral das Obrigações. São Paulo: Editora Saraiva, 2005, p. 83.
} 


\subsection{PUBLICIDADE COMPARATIVA COMO FERRAMENTA DO CONSUMIDOR}

Como vimos, o fornecedor tem a obrigação de apresentar ao consumidor informações claras, completas e verídicas acerca do produto ou serviço que oferece no mercado. Vimos, ainda, o papel da publicidade na veiculação de tais informações e os parâmetros que devem ser seguidos pelos anunciantes.

Nessa toada, nos parece óbvio que a publicidade comparativa seria mais uma ferramenta que permitiria aos anunciantes cumprir com seu dever informacional perante os consumidores.

A esse respeito, o CONAR já se manifestou em sentido idêntico ${ }^{121}$ :

A propaganda comparativa é uma técnica válida e atual, desde que respeitadas as normas éticas do negócio da propaganda. Entende-se aí, que os produtos comparados devem ser expostos de igual maneira, sem prejudicar o concorrente. Os textos devem ser informativos e exatos, evitando-se sofismas, ou dúbia interpretação.

A propaganda comparativa é, na realidade, um instrumento do consumidor, pois através dela ele terá opções de decisão (...).

Há que se ter em mente que a comparação é movimento corriqueiro no mercado de consumo, fazendo parte do processo de seleção realizado pelos consumidores na aquisição de produtos e serviços. Lembramos que é comum que periódicos e revistas especializados de determinados segmentos (como automóveis, eletrônicos e informática, por exemplo) publiquem testes comparativos entre diversos produtos ${ }^{122}$. A esse respeito, assim se posiciona GARCIA ${ }^{123}$ :

\footnotetext{
${ }^{121}$ Representação no 013/79 do CONAR

122 "É o caso, por exemplo, dos resultados comparativos publicados por revistas especialziadas quanto ao desempenho de automóveis testados por sua equipe técnica. Outra situação corriqueira é o da revista ou guia de turismo que afere comparativamente a excelência dos serviços prestados por companhias aéreas, hotéis ou agências de viagens, divulgando os resultados obtidos junto aos seus leitores. Também são usuais os testes empreendidos por institutos de pesos e medidas e instituições congÇeneres quando à idoneidade e segurança de produtos no mercado. Mais recentemente, tornaram-se habituais as comparações de preços de CDs, livros e outros produtos, feitas por instrumentos de busca na Internet". SCHMIDT, Lelio Denicoli. A publicidade comparativa
} 
En todo este proceso de evaluación, e independientemente de la fuente que utilicen, los consumidore están realizando constantemente comparaciones entre marcas para decidirse por la mejor opción. En este sentido, la publicidad comparativa puede ayudar al consumidor em su proceso de elección, que es comparativo por naturaleza, suministrandole información sobre diversas marcas y presentandole las ventajas reales de unas sobre otras de acuerdo a determinados atributos importantes del producto $^{124}$.

Desta forma, a publicidade comparativa seria uma ferramenta para aprimorar o processo de escolha do consumidor, abreviando as comparações $^{125}$ e ressaltando, ainda, as diferenças entre os diversos produtos disponíveis no mercado.

Além de beneficiar diretamente os consumidores, ao aumentar o nível de informação disponível, vários autores destacam ainda os benefícios indiretos que adviriam da publicidade comparativa, através do fomento à concorrência entres os diversos players do mercado, como bem destaca PLAZA ${ }^{126}$ :

à luz da propriedade industrial. Revista da Associação Brasileira da Propriedade Industrial, Rio de Janeiro, n. 52, Mai/Jun de 2001, p. 14-15.

${ }^{123}$ GARCÍA, Salvador Del Barrio. Apud PEREIRA, Marco Antonio Marcondes. A ilicitude da publicidade comparativa. São Paulo: PUC-SP, 2008. 237 p. Tese (Doutorado) - Doutorado em Direito, Pontifícia Universidade Católica de São Paulo, São Paulo, 2008.

124 Tradução livre: "Em todo esse processo de avaliação, e independentemente da fonte que utilizem, os consumidores estão realizando constantemente comparações entre marcas para decidir pela melhor opção. Neste sentido, a publicidade comparativa pode ajudar o consumidor em seu processo de escolha, que é comparativo por natureza, fornecendo-lhe informação sobre diversas marcas e apresentando-Ihe as vantagens reais de umas sobre outras de acordo com determinados atributos importantes do produto".

125 "A publicidade comparativa, sob o ponto de vista dos que a concebem como viável e lícita, apresenta-se como fonte de melhor informação para os consumidores na hora de decidir pela compra de um produto ou contratação de um serviço.

$O$ argumento parte da noção de que a sociedade de massa oferta uma multiplicidade de produtos e serviços no mercado, todos oriundos de empresários fornecedores que disputam fortemente a preferência do público. Tal diversidade faz com que o consumidor tenha de decidir com mais rapidez e segurança no momento de compra, por um lado, e, por outro lado, é de se considerar a variedade de publicidade existente.

A publicidade comparativa surge como meio de abreviar a comparação natural que o consumidor faria a custo de muito tempo, além de, em segundo argumento favorável, se prestar a promover a mais transparência no mercado e fomentar a concorrência entre os empresários (...)".PEREIRA, Marco Antonio Marcondes. A ilicitude da publicidade comparativa. São Paulo: PUC-SP, 2008. 237 p. Tese (Doutorado) - Doutorado em Direito, Pontifícia Universidade Católica de São Paulo, São Paulo, 2008.

${ }^{126}$ PLAZA, Anxo Tato. Apud PEREIRA, Marco Antonio Marcondes. A ilicitude da publicidade comparativa. São Paulo: PUC-SP, 2008. 237 p. Tese (Doutorado) - Doutorado em Direito, Pontifícia Universidade Católica de São Paulo, São Paulo, 2008. 
Según los autores que propugnan la admision de las comparaciones publicitárias, el interes general también aboga por la admision de la publicidad comparativa por los efectos beneficiosos que de aquella se derivan para el progreso técnico y económico.

Em efecto, mediante la publicad comparativa el anunciante va a dar a conocer al público la mayor calidad o el menor precio de su oferta rente a La de uno o vários competidores. A partir de entonces, el competidor o competidores afectados se verán obligados a mejorar la calidad de sus productos o a reducir su precio, pues, de outro modo, dificilmente podrán sobrevivir em la lucha econômica.

$(\ldots)$

Em definitiva, se puede afirmar que a través de la publicidad comparativa se intensifica la competência entre las empresas, viendose estas obligadas a acometer mejoras em sus productos y a reduzir (em La medida de lo posible) sus precios; se fomenta, de este modo, el progreso técnico y económico $^{127}$.

Alguns autores, por outro lado, mostram-se contrários à aplicação da técnica da comparação publicitária, sustentando que esta traria sempre informações incompletas e unilaterais sobre os produtos comparados e acabariam por trazer mais confusão do que esclarecimento ao consumidor $^{128}$.

Entretanto, não nos parece correto afirmar que a parcialidade ou seleção de informações seria fenômeno exclusivo da publicidade

\footnotetext{
${ }^{127}$ Tradução livre: "Segundo os autores que propagam a admissão das comparações publicitárias, o interesse geral também advoga pela admissão da publicidade comparativa pelos efeitos benéficos que dela derivam para o progresso técnico e econômico. Com efeito, mediante a publicidade comparativa o anunciante vai dar a conhecer ao público a maior qualidade ou o menor preço de sua oferta frente aos de um ou vários competidores. A partir de então, o competidor ou competidores afetados se verão obrigados a melhorar a qualidade de seus produtos ou a reduzir o preço, pois, de outro modo, dificilmente poderão sobreviver à luta econômica. (...) Em definitivo, se pode afirmar que através da publicidade comparativa se intensifica a concorrência entre as empresa, vendo-se estas obrigadas a realizar melhorias em seus produtos e a reduzir (na medida do possível) seus preços; se fomenta, deste modo, o progresso técnico e econômico".

${ }_{128}$ Nesse sentido: "As limitações de informações em razão do veículo utilizado se traduzem em comparações incompletas na publicidade comparativa, de pouca utilidade para o consumidor, além de causar prejuízo ao consumidor por conta da confusão entre produtos ou serviços, ou ainda sobre a validade dos critérios de distinção adotados pelo anunciante para considerar seus produtos ou serviços melhores que o da concorrência". PEREIRA, Marco Antonio Marcondes. A ilicitude da publicidade comparativa. São Paulo: PUC-SP, 2008. 237 p. Tese (Doutorado) Doutorado em Direito, Pontifícia Universidade Católica de São Paulo, São Paulo, 2008.
} 
comparativa, sendo certo que tal situação se repete em qualquer tipo de anúncio, como bem esclarece Lélio Denicoli Schmidt ${ }^{129}$ :

Diante do alto custo do espaço publicitário, as mensagens que nele são veiculadas têm extensão limitada. Isto restringe o conteúdo que a mensagem pode ter, levando a uma seleção natural do que deve ou não vir a integrá-la. Neste cenário, não há a obrigatoriedade da mensagem abarcar todos os pontos, positivos ou não, do produto ou serviço anunciado. Sendo por natureza tendenciosa, a mensagem publicitária pode se ater apenas aos aspectos positivos que sejam mais favoráveis para persuadir o consumidor a adquirir o produto ou serviço anunciado.

Desta forma, a parcialidade ou seleção de informações pelo anunciante, por ser inerente à própria atividade publicitária, não nos parece um óbice para a aceitação da publicidade comparativa, ou também deveria sê-lo para as demais técnicas publicitárias.

Concluímos, destarte, que o aumento do nível informacional pode provocar o incremento da competitividade em determinados segmentos do mercado e levar os fornecedores a oferecer preços ou condições de compra mais atrativos aos consumidores ou, ainda, investir em tecnologia e inovação ${ }^{130}$.

\footnotetext{
${ }^{129}$ SCHMIDT, Lelio Denicoli. A publicidade comparativa à luz da propriedade industrial. Revista da Associação Brasileira da Propriedade Industrial, Rio de Janeiro, n. 52, Mai/Jun de 2001, p. 4.

130 "Comparative advertising encourages product improvement and innovation, and can lead to lower prices in the marketplace". Tradução livre: "Publicidade comparative encoraja melhorias nos produtos e inovação, e pode lever a menores preços no Mercado de consumo". UNITED STATES FEDERAL TRADE COMISSION. Statement of Policy Regarding Comparative Advertising. Disponível em <http://www.ftc.gov/bcp/policystmt/ad-compare.htm>, acesso em 15/03/2011.
} 


\section{CONCLUSÃO}

O estudo realizado ao longo do presente trabalho buscou analisar e esclarecer os aspectos legais que permeiam a aplicação da técnica da comparação na publicidade.

Pudemos verificar que, na legislação alienígena estudada, a publicidade comparativa é amplamente aceita e até mesmo incentivada. No mesmo sentido, verificamos que os usos e costumes do mercado publicitário brasileiro, consolidados no Código de Ética do CONAR, também admitem o emprego da técnica.

Concluímos que, muito embora não exista no Brasil previsão legal específica que discipline a matéria, a publicidade comparativa não encontra, a priori, nenhum óbice na legislação pátria. Nessa toada, verificamos que a menção ou citação da marca do concorrente comparado não constitui violação aos seus direitos marcários e, concluímos, ainda, que o uso de conceitos publicitários ou paródias de anúncios não constituem violação aos direitos autorais do concorrente comparado.

Percorremos, ainda, a legislação consumerista e os princípios que orientam a atividade publicitária concluindo que, para ser lícita e aceitável, toda forma de publicidade deve obedecer ao princípio geral da boa-fé, presente tanto no Código Civil quanto no Código de Defesa do Consumidor, bem como observar os princípios da transparência máxima nas relações de consumo, da veracidade e da não-abusividade da publicidade.

Destarte, entendemos que a publicidade comparativa não deve ser considerada, per se, abusiva ou enganosa, devendo ser aplicados a esta os mesmos filtros e parâmetros cabíveis a quaisquer outras técnicas publicitárias $^{131}$.

131 ") However industry codes and interpretations that impose a higher standard of substantiation for comparative claims than for unilateral claims are inappropriate and should be revised". Tradução livre: “(...) Entretanto, códigos de determinados indústrias e interpretações que impõem parâmetros de comprovação mais altos para anúncios comparativos do que para anúncios unilaterais são inapropriados e devem ser revistos". UNITED STATES FEDERAL TRADE 
Por fim, concluímos que a publicidade comparativa é uma técnica publicitária que pode incrementar o nível informacional dos consumidores, contribuindo para escolhas de consumo conscientes. Concluímos, ainda, que o emprego da comparação pode fomentar a concorrência e impulsionar o progresso técnico em determinados mercados.

COMISSION. Statement of Policy Regarding Comparative Advertising. Disponível em <http://www.ftc.gov/bcp/policystmt/ad-compare.htm>, acesso em 15/03/2011. 


\section{BIBLIOGRAFIA}

ABRÃO, Eliane Yachouh. Direitos de autor e direitos conexos. São Paulo: Editora do Brasil, 2002.

AMATRUDO, Rosangela. Publicidade Abusiva. In: Revista de Direito do Consumidor. n.52.outubro-dezembro. São Paulo: Editora Revista dos Tribunais. 2004.

ASCENSÃO, José de Oliveira. Direito Autoral. 2. ed., ref. e ampl. Rio de Janeiro: Renovar, 1997.

BENJAMIN, Antonio Hermann de Vasconcellos e. Código Brasileiro de Defesa do Consumidor comentado pelos autores do anteprojeto. 8. Ed. Rio de Janeiro: Forense, 2005.

BARBOSA, Denis Borges. Uma introdução à propriedade intelectual. Rio de Janeiro: Lúmen Júris, 1997.

Proteção de marcas. Rio de Janeiro: Lumen

Juris, 2007

BARBOSA, Pedro Marcos Nunes. Liberdade de Expressão e Signos Distintivos na Internet. Revista Eletrônica do Instituto Brasileiro da Propriedade Intelectual. vol. 03. 2010.

BAUMAN, Zygmunt. Modernidade Líquida. Rio de Janeiro: Zahar Editora, 2001.

BITTAR, Carlos Alberto. Contornos atuais do direito do autor, $2^{\mathrm{a}} \mathrm{Ed}$., revista, atualizada e ampliada. São Paulo: Revista dos Tribunais, 1999.

BRASIL. Constituição Federal de 1988, disponível em http://www.presidencia.gov.br/legislacao/, acessado em 24.03.2008, às 13:58.

BRASIL. Lei no $\mathbf{9 . 2 7 9}$ de 1996, disponível em http://www.presidencia.gov.br/legislacao/, acessado em 24.03.2008, às 13:50.

BRASIL. Lei no 10.406 de 2002, disponível em http://www.presidencia.gov.br/legislacao/, acessado em 24.03.2008, às 13:50. 
BRASIL. Lei no $\mathbf{8 . 0 7 8}$ de 1990, disponível em http://www.presidencia.gov.br/legislacao/, acessado em 24.03.2008, às 13:50.

BRASIL. Tribunal Regional Federal da $2^{2}$ Região, julgados disponíveis no sítio http://www.trf2.gov.br, acessado em 24.03.2008, às 13:34.

CERQUEIRA, João da Gama. Atualizao por BARBOSA, Denis Borges e SILVEIRA, Newton. Tratado da propriedade industrial, Vol I, Parte I, Rio de Janeiro: Editora Forense, 1946.

. Tratado da propriedade industrial. Rio de Janeiro: Editora Forense, 1952, Vol II, Tomo I.

CERQUEIRA, João da Gama. Tratado da Propriedade Industrial, Vol. II, Tomo II, Parte III, Rio de Janeiro: Editora Forense, 2010.

COELHO, Daniele Maia Teixeira. A publicidade comparativa e seu tratamento legal. Revista Forense, Vol. 354, 2001.

COELHO, Fábio Ulhoa. Curso de Direito Comercial. Volume $1,11^{\mathrm{a}}$ edição - Saraiva - São Paulo - 2007

A publicidade enganosa no Código de Defesa do Consumidor. In Revista do Direito do Consumidor. São Paulo: Editora Revista dos Tribunais. Outubro/Dezembro,1993.

DANNEMANN, SIEMSEN, BIGLER \& IPANEMA MOREIRA. Comentários à lei da propriedade industrial e correlatos. Rio de Janeiro: Renovar, 2005.

Comentários à lei de propriedade industrial e correlatos. Rio de Janeiro: Renovar, 2001.

DA SILVA, Regina Beatriz Tavares da e POLETTO, Carlos Eduardo Minozzo. Responsabilidade Civil pela Publicidade. In SILVA, Regina Beatriz Tavares da (coord.), Responsabilidade Civil nas relações de consumo. São Paulo: Saraiva, 2009.

DE LUCCA, Newton. Direito do Consumidor: aspectos práticos perguntas e respostas. 2. Ed. Bauru: EDIPRO, 2000. Apud DA SILVA, Regina Beatriz Tavares da e POLETTO, Carlos Eduardo Minozzo. Responsabilidade Civil pela Publicidade. In SILVA, Regina Beatriz Tavares da (coord.), Responsabilidade Civil nas relações de consumo. São Paulo: Saraiva, 2009.

DIRECTIVA 2004/27/CE do parlamento europeu e do conselho, de 31 de Março de 2004, disponível em http://eurlex.europa.eu/LexUriServ/LexUriServ.do?uri=OJ:L:2005:149:0022:003 9:PT:PDF, acessado em 24.03.2008, às 13:45. 
JACOBINA, Paulo Vasconcelos. A Publicidade no Direito do Consumidor. Rio de Janeiro: Editora Forense, 1996.

LÔBO, Paulo Luiz Netto. Teoria Geral das Obrigações. São Paulo: Editora Saraiva, 2005.

MARQUES, Claudia Lima. A nova crise do contrato: Estudos sobre a nova teoria contratual. Ed. Revista dos Tribunais; São Paulo, 2007.

MARTINS, Guilherme Magalhães. Responsabilidade Civil por Acidente de Consumo na Internet. Editora Revista dos Tribunais; São Paulo; 2008.

MAZZONETTO, Natalia. A publicidade comparativa e a prática de concorrência desleal por meio do denegrimento de marca e da imagem do concorrente. Revista da Associação Brasileira da Propriedade Industrial, Rio de Janeiro, n. 99, Mar/Abr de 2009, p. 3-20.

NEGREIROS, Teresa. Teoria do Contrato, Novos Paradigmas. Editora Renovar, Rio de Janeiro, 2006.

PASQUALOTTO, Adalberto. Os Efeitos Obrigacionais da Publicidade o Código de Defesa do Consumidor. São Paulo: Editora Revista dos Tribunais. 1997.

PEREIRA, Marco Antonio Marcondes. A ilicitude da publicidade comparativa. São Paulo: PUC-SP, 2008. 237 p. Tese (Doutorado) Doutorado em Direito, Pontifícia Universidade Católica de São Paulo, São Paulo, 2008.

. Concorrência desleal por meio da publicidade, São Paulo: Juarez de Oliveira, 2001.

PLAZA, Anxo Tato. La Publicidad Comparativa. Madrid: Marcial Pons, 1996.

SCHMIDT, Lelio Denicoli. A publicidade comparativa à luz da propriedade industrial. Revista da Associação Brasileira da Propriedade Industrial, Rio de Janeiro, n. 52, Mai/Jun de 2001, p. 3-17.

UNITED STATES FEDERAL TRADE COMISSION. Statement of Policy Regarding Comparative Advertising. Disponível em <http://www.ftc.gov/bcp/policystmt/ad-compare.htm>, acesso em 15/03/2011.

ZULIANI, Ênio Santarelli. Direitos básicos do consumidor. In SILVA, Regina Beatriz Tavares da (coord.), Responsabilidade Civil nas relações de consumo. São Paulo: Saraiva, 2009. 